\title{
Production of starch aerogel in form of monoliths and microparticles
}

\author{
Victor Baudron $^{1} \cdot$ Martha Taboada $^{2} \cdot$ Pavel Gurikov $^{1} \cdot$ Irina Smirnova $^{1} \cdot$ Steve $^{\text {Whitehouse }}{ }^{3}$
}

Received: 13 June 2019 /Revised: 18 December 2019 / Accepted: 12 February 2020 / Published online: 16 March 2020

(C) The Author(s) 2020

\begin{abstract}
Pea and amylomaize starches were used to produce aerogel in form of monoliths and microparticles. The formation of starch gel was investigated, and we showed that each starch needed a different pasting temperature for its complete dissolution. The gelation kinetics was investigated with oscillatory rheometry for both systems as a function of the starch concentration. The gelation and retrogradation temperature of the starch gel were varied and its impact on the final aerogel evaluated. The emulsion gelation was carried out batch wise in a stirred vessel with different impeller geometries, concentrations of surfactant (Span80 and PGPR) and stirring rates. A particle size prediction approach based on idealized flow (Couette, 2D hyperbolic and turbulent) during the emulsification was proposed. A semi-continuous set-up for the emulsion gelation was developed in which the emulsification occurs in a single pass through a colloid mill and the gelation is triggered in-line with a counter-current heat exchanger.
\end{abstract}

Keywords Starch $\cdot$ Pea $\cdot$ Amylomaize $\cdot$ Pasting $\cdot$ Gelation $\cdot$ Rheometry $\cdot$ Aerogel $\cdot$ Emulsion

\begin{tabular}{|c|c|}
\hline Abbre & ations \\
\hline Variab & \\
\hline $\mathrm{Ca}$ & [-] Capillary number \\
\hline $\mathrm{C}_{1}$ & $\begin{array}{l}\text { [-] Parameter in de Bruijn fitting for } \\
\text { critical capillary number }\end{array}$ \\
\hline $\mathrm{C}_{2}$ & $\begin{array}{l}{[-] \text { Parameter in de Bruijn fitting for }} \\
\text { critical capillary number }\end{array}$ \\
\hline $\mathrm{Ca}_{\text {crit }}$ & [-] Critical capillary number \\
\hline $\mathrm{D}$ & $\begin{array}{l}\text { [m] Diameter of the impeller or of } \\
\text { the colloid mill rotor }\end{array}$ \\
\hline $\mathrm{d}$ & [m] Diameter of the droplet \\
\hline$d_{\max }$ & [m] Largest stable droplet in emulsion \\
\hline $\mathrm{d}_{\mathrm{T}}$ & [m] Vessel diameter \\
\hline $\mathrm{h}_{\mathrm{em}}$ & [m] Emulsion height in vessel \\
\hline $\mathrm{h}_{\mathrm{I}}$ & [m] Impeller height \\
\hline $\mathrm{h}_{\mathrm{T}}$ & [m] Vessel height \\
\hline
\end{tabular}

Victor Baudron

victor.baudron@tuhh.de

1 Institute of Thermal Separation Processes, Hamburg University of Technology (TUHH), 22073 Hamburg, Germany

2 Institute of Food Process Engineering (LVT), Karlsruhe Institute of Technology (KIT), 76131 Karlsruhe, Germany

3 Nestlé Product Technology Centre York, Haxby Road, PO Box 204, York YO91 1XY, UK

$\begin{array}{ll}\mathrm{K} & \begin{array}{l}{[\text { Pa.s }] \text { Parameter of the power }} \\ \text { law model }\end{array} \\ \mathrm{n} & {[-] \text { Parameter of the power law model }} \\ \mathrm{N} & {\left[\mathrm{min}^{-1}\right] \text { Rotational speed in RPM }} \\ \mathrm{V}_{\text {oil }} & {\left[\mathrm{m}^{3}\right] \text { Volume of the oil phase }} \\ \mathrm{V}_{\text {trigger }} & {\left[\mathrm{m}^{3}\right] \text { Volume of trigger phase }} \\ \mathrm{W} & {[\mathrm{m}] \text { Impeller width }} \\ \mathrm{W}_{\text {baffle }} & {[\mathrm{m}] \text { Baffle width }}\end{array}$

\section{Greek letters}

$\alpha \quad[-]$ Parameter in de Bruijn fitting for critical capillary number

$\lambda \quad[-]$ Viscosity ratio

$\lambda_{\text {app }} \quad[-]$ Apparent viscosity ratio

$\lambda_{\max }$ [-] Parameter in de Bruijn fitting for critical capillary number

$\dot{\gamma} \quad\left[\mathrm{s}^{-1}\right]$ Shear rate

$\bar{\gamma} \quad\left[\mathrm{s}^{-1}\right]$ Average shear rate

$\gamma_{\max }\left[\mathrm{s}^{-1}\right]$ Maximal shear rate

$\mu \quad$ [Pa.s] Dynamic viscosity

$\rho \quad\left[\mathrm{kg} \cdot \mathrm{m}^{3}\right]$ density

$\omega \quad\left[\mathrm{rad} . \mathrm{s}^{-1}\right]$ Rotational speed of the impeller or rotor
Abbreviations
BET Brunauer-Emmett-Teller
CMC Critical micellar concentration
HE Heat Exchanger 
IFT Interfacial tension

RPM Rotation per minute

RSM Rotor stator machine

SEM Scanning election microscope

\section{Introduction}

Aerogels are mesoporous low density open porous materials with large specific surface area and high specific pore volume. Such properties give them a wide range of potential applications, from carrier material to superinsulation. Aerogel production usually starts with the formation of a gel in water or in an organic solvent. Polysaccharide gels are usually formed in water, which have to be exchanged with an organic solvent to allow for the supercritical drying. During the drying, carbon dioxide and organic solvent form a single supercritical phase that can be removed from the gel while preserving its pore structure.

A wide variety of known gel forming systems gives rise to aerogels with diverse chemical compositions such as inorganic oxides, polysaccharides and synthetic polymers. When gelled in a mould, aerogels adopt its shape. Many examples of monolithic aerogels prepared from synthetic polymers [1-4], cellulose [5-7], pectin [8-10] and alginate [11-13] can be found in the literature.

Starch, being a widely abundant native biopolymer, has attracted attention of the aerogel research: Mehling et al. [14], Marco et al. [15], Ubeyitogullari and Ciftci [16], De Marco and Reverchon [17] and Goimil et al. [18] produced starch aerogel with specific surface areas between 60 and $100 \mathrm{~m}^{2} / \mathrm{g}$. Higher values between 220 and $254 \mathrm{~m}^{2} / \mathrm{g}$ have been reported by Garcia-Gonzalez et al. [19] and Druel et al. [20]. Kenar et al. reached up to $362 \mathrm{~m}^{2} / \mathrm{g}$ by forming starch-sodium palmitate complexes [21].

Prior research therefore shows that a significant fraction of the overall porosity can be preserved upon conversion into aerogels. Although there is a broad-spectrum of available shaping techniques [22] [23] for gelling systems, such as spraying and jet cutting, little attention has so far been paid to shaping starch aerogels, especially to the production of regular spherical microparticles.

As we reviewed in the work [23], gel microparticles can be obtained via so called emulsion gelation (Fig. 1). In this process, a gelling solution is dispersed in an immiscible oil, and the droplet size is tuned by varying the stirring rate, the emulsifier concentration and other parameters. Once the droplets reach the proper dimensions, the gelation is triggered either by a chemical impact, such as addition of a chemical gelation trigger (e.g. calcium chloride solution for the alginate system [24]), or by a physical impact such as heating (e.g. for proteins [25]) or cooling (e.g. for starch [19]). The gel (micro) particles can then be separated from the oil phase and further processed into aerogel in the same way as their monolithic counterparts.
Particle size and shape of the resulting aerogels are primarily determined by processes in the emulsion, and thus a rational understanding of the process and subsequent scale-up should begin with a closer look at the emulsification step.

Despite the fact that emulsion gelation has been used at lab scale with several polysaccharides such as pectin [26], alginate $[26,27]$ and starch $[19,26]$ and also with synthetic polymers [28, 29] and inorganic systems such as silica [30], only batch processes have been reported either with standard impeller or with batch rotor-stator machines. This led Ching et al. [22] to a conclusion that throughput of the emulsion gelation in its batch implementation is strongly limited. To this end, a continuous emulsion gelation could potentially overcome this problem, but such a process has never been reported for the starch system, to the best of our knowledge.

In the present work, we aim to fill the abovementioned gaps by elucidating mechanisms involved into particle formation in the emulsion gelation in order to pave the way to a continuous production of gel and aerogel starch microparticles.

\section{Material and methods}

\section{Chemicals}

Amylomaize (High Amylose Corn Starch AMYLO N-460) and pea (Pea Native Starch N-735) starches, with an amylose content of respectively $66 \mathrm{wt} . \%$.and $45 \mathrm{wt} . \%$ (information provided by furnisher), were kindly provided by Roquette Frere $₫$ (Lestrem, France). High- and low-viscosity mineral oil (Carl Roth $\mathrm{GmbH}$ ) and rapeseed oil (Henry Lamotte) were used to prepare emulsions. Their densities at $20{ }^{\circ} \mathrm{C}$ are respectively 880,850 and $920 \mathrm{~kg} / \mathrm{m}^{3}$, and their viscosities were measured at different temperatures and reported in the results part. Sorbitan monooleate, referred as to Span80 (Merck KGaA), and polyglycerol polyricinoleate, referred as to PGPR (PGPR-4150 from Palsgaard), were used as surfactant. Their molecular weights are respectively 428 and $520 \mathrm{~g} / \mathrm{mol}$. For the separation and solvent exchange, ethanol solutions were prepared from denatured ethanol (99.8 wt.\%) purchased from Carl Roth $\mathrm{GmbH}$.

\section{Pasting}

To prepare the starch paste, starch was suspended in cold water in the proportion needed to reach the desired mass fraction. The suspension was then poured into the 200-mL PTFE insert of the pasting autoclave together with a stirring fish. Once the autoclave sealed, the electrical heating was turned on and the temperature increased. The heating duration until the desired temperature varied between 30 and 40 min depending on the desired pasting temperature (ranging between 130 and $140{ }^{\circ} \mathrm{C}$ ). The temperature was then hold for $20 \mathrm{~min}$ 
Fig. 1 General scheme of the emulsion gelation method for the starch system



1.

Starch paste emulsification (in hot oil)

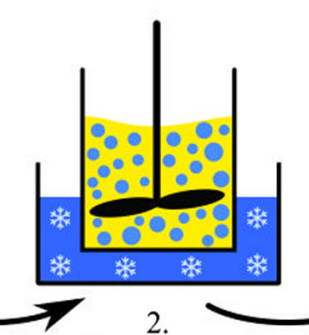

Starch paste droplets gelation (cooling)



3.

Starch gel particles Starch gel particles separation via decantation solvent exchange and sc-drying

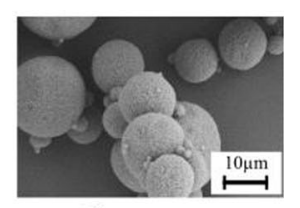

4. before actively cooling the suspension to $90{ }^{\circ} \mathrm{C}$ before opening the autoclave to avoid boiling and water loss.

\section{Gelation investigation with small oscillatory rheology}

A rotational rheometer (Malvern Kinexus Pro+) was used for the viscosity measurements and for the investigation of the starch gelation with small oscillation experiments. The viscosity measurements were done with a stainless steel cone and plate geometry (60-mm diameter $-1^{\circ}$ angle) and a gap of $0.04 \mathrm{~mm}$. To minimize evaporation of water, a solvent trap was used, and paraffin oil was applied to the edge to avoid sample drying during the measurement. Before depositing the freshly pasted starch $\left(\sim 85^{\circ} \mathrm{C}\right)$, the cone and plate were preheated to $80^{\circ} \mathrm{C}$. The oscillatory experiments were done with a plate-plate geometry ( $20 \mathrm{~mm}$ diameter) and a gap of $0.8 \mathrm{~mm}$. The solvent trap and paraffin oil were also used to minimize the water evaporation during the experiment.

\section{Emulsification}

Batch emulsifications were carried out in a stirred vessel $\left(d_{T}=\right.$ $66 \mathrm{~mm}$ ) equipped with four baffles $\left(w_{\text {baffle }}=9 \mathrm{~mm}\right)$. Two impellers were compared, a flat blade turbine (FBT) with diameter $D=35 \mathrm{~mm}$ and height $h_{I}=10 \mathrm{~mm}$ and $45^{\circ}$ pitched blade turbine (PBT) with diameter $D=38 \mathrm{~mm}$ and height $h_{I}=9 \mathrm{~mm}$, both of them equipped with four blades. The impeller was placed at $3 d_{I}$ from the bottom of the vessel, and the fluid level was $h_{e m}=$ $d_{T}$, producing an emulsification volume of $200 \mathrm{~mL}$. The phase ratio $\Phi=V_{\text {disp }} / V_{\text {tot }}$ was maintained to $20 \mathrm{v} \%$. After stirring for $10 \mathrm{~min}$, a 1-mL sample was taken for analysis and cooled rapidly to $3{ }^{\circ} \mathrm{C}$ to induce a quick gelation of the emulsion droplets so that the particle size distribution of the gel microparticles represented the droplet size distribution in the emulsion.

Semi-continuous emulsifications were carried out with a colloid mill (MagicLab IKA Germany) which rotor had an upper diameter of $22.8 \mathrm{~mm}$ and lower diameter of $31.9 \mathrm{~mm}$. Two set-ups were used with the emulsification device as shown in Figs. 2 and 3. With the first one, a coarse emulsion was produced in a jacketed vessel at $80^{\circ} \mathrm{C}$ with the PBT at 400 $\mathrm{RPM}$ for $5 \mathrm{~min}$ and then processed in a one pass through the colloid mill operated at various rotational speeds and gap widths. A $1-\mathrm{mL}$ sample was cooled down rapidly to $3{ }^{\circ} \mathrm{C}$ for analysis and the rest cooled down in a cooling bath.

The second semi-continuous set-up (Fig. 3) consists of a 2-L pasting autoclave equipped with mechanical stirring and a thermostated oil vessel. Once the pasting was finished, the temperature of the starch melt was brought down to the processing temperature, and pressurized air was used to push the starch paste and the oil to the colloid mill. The flow rate could be controlled with the air pressure and by adjusting the valves V1 and V2 that also allowed to control the phase ratio.

With this set-up, a coaxial coil heat exchanger (Table 1) was used to cool down the emulsion and trigger the gelation of the starch paste droplets. It was operated in counter-current mode with cooling water temperature between 17 and $19^{\circ} \mathrm{C}$. The three-way valve V3 was used to take samples before the heat exchanger, which were cooled rapidly and analysed for comparison.

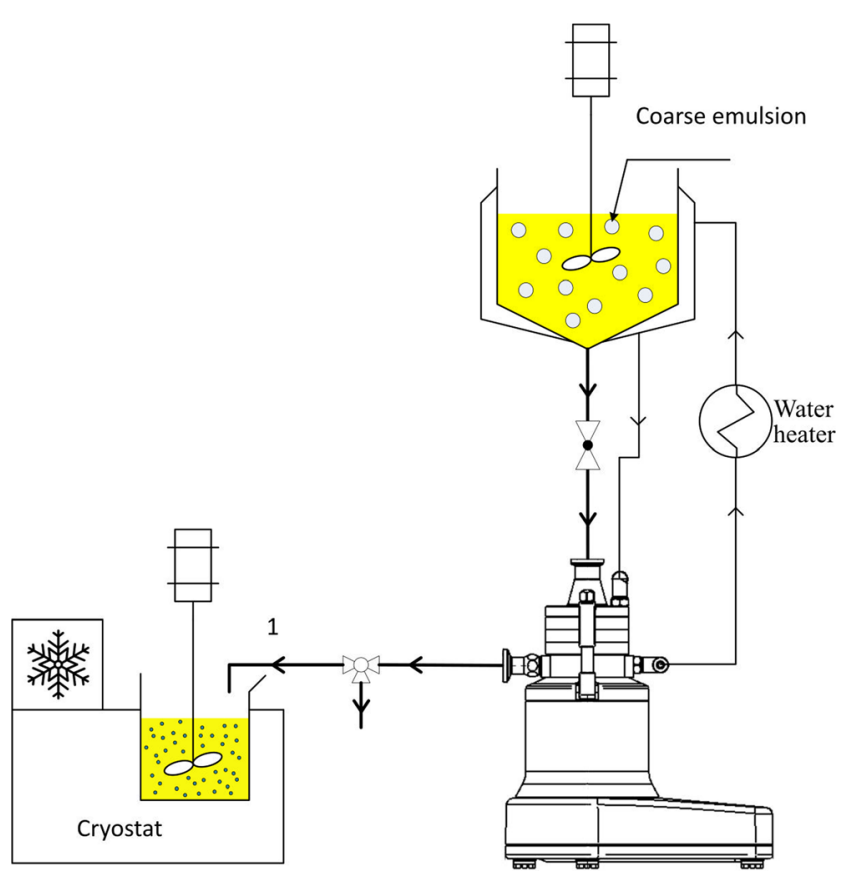

Fig. 2 Semi-continuous set-up: The coarse emulsion is prepared in a stirred vessel before being processed by the colloid mill 
Fig. 3 Semi-continuous set-up for the production of starch gel microparticles using an in-line colloid mill as the emulsification device

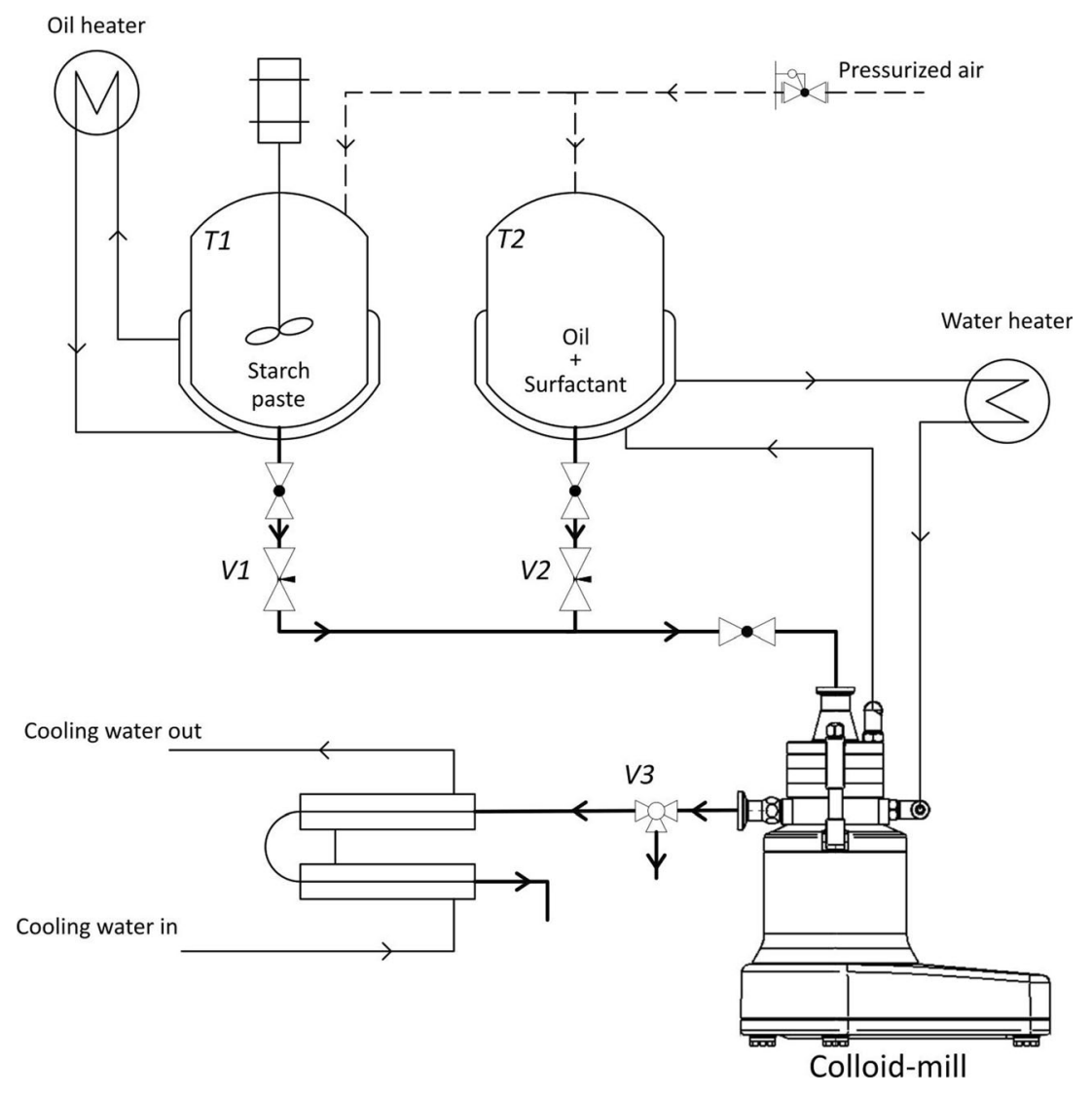

\section{Particle size distribution measurement}

The droplet size distribution of the emulsion was measured by analysing micrographs taken with ten-time magnification objective. Pictures were taken and each droplet/particle was counted one by one with an image analysis program written in Python. Several nonoverlapping pictures were analysed so that more than 1000 different droplets were counted per analysis. Each experiment is repeated twice, and the error bars on the droplet and particle size reported in the graphs correspond to the standard deviation of the two repetitions. The $d_{v 90}$, the 90th percentile of the volume distribution (diameter for which $90 \%$ of the total droplet volume is contained in the droplets of diameter $\mathrm{d} \leq$ $\mathrm{d}_{\mathrm{v} 90}$ ), was taken as the experimental value for the largest stable drop in emulsion similarly to the work by Vankova et al. [31].

\section{Separation, solvent exchange and supercritical drying}

To separate the gel microparticles from the oil, a heavier aqueous phase (water or $30 \mathrm{wt} \%$ ethanol) is added. The gel particles being denser than the oil and the aqueous phase, sediment at the bottom of the vessel, can be withdrawn with the aqueous phase.

Subsequently the solvent exchange was done by letting the particles sediment at the bottom of the aqueous phase, removing the supernatant and adding fresh pure ethanol. After gently stirring for $10 \mathrm{~min}$, the cycle was repeated until the ethanol

concentration in the bulk phase reached the desired concentration for drying (>95\%). The solvent exchange of the starch gel monoliths was done in a similar manner, but the system was let to equilibrate overnight before changing the ethanol.

For the supercritical drying, the particles were packed in filter paper and introduced in the supercritical drying autoclave $(250 \mathrm{~mL}$, with electrical heating controlling), preheated to $60{ }^{\circ} \mathrm{C}$. The drying was then performed at 120 bar with a continuous flow of $\mathrm{CO}_{2}$ at $60^{\circ} \mathrm{C}(\sim 20 \mathrm{~g} / \mathrm{min})$ for $3 \mathrm{~h}$.

\section{Results and discussion}

\section{Starch pasting}

The first step in the elaboration of starch aerogels is the formation of a starch gel. To this end, the starch is

Table 1 Specification of coaxial heat exchanger

\begin{tabular}{ll}
\hline Length & $6 \mathrm{~m}$ \\
Coil internal diameter & $260 \mathrm{~mm}$ \\
Number of turns & 7 \\
Internal tube inner diameter & $15 \mathrm{~mm}$ \\
External tube outer diameter & $24 \mathrm{~mm}$ \\
Tubes thickness & $1 \mathrm{~mm}$ \\
Inner surface area & $0.55 \mathrm{~m}^{2}$
\end{tabular}


Fig. 4 Evolution of the amylomaize starch granule integrity for different pasting temperatures. a no pasting. b $120^{\circ} \mathrm{C}$. c $130^{\circ} \mathrm{C}$. d $140^{\circ} \mathrm{C}$. The scale bar represents $80 \mu \mathrm{m}$



dissolved in water at high temperature with an autoclave in a step called pasting.

The pasting temperature was varied for $1 \mathrm{wt} \%$ pea and amylomaize starches slurry and pictures were taken after the pastings (Figs. 4 and 5). It can be observed that the unprocessed pea starch granules are almost two times larger than the amylomaize ones, reminding that starch is a natural product which composition and shape vary with its origin. For temperature below $140{ }^{\circ} \mathrm{C}$, no complete dissolution of the amylomaize starch was
Fig. 5 Evolution of the pea starch granule integrity for different pasting temperatures. a No pasting. b $105^{\circ} \mathrm{C}$. c $120^{\circ} \mathrm{C}$. d $130^{\circ} \mathrm{C}$. The scale bar represents $80 \mu \mathrm{m}$

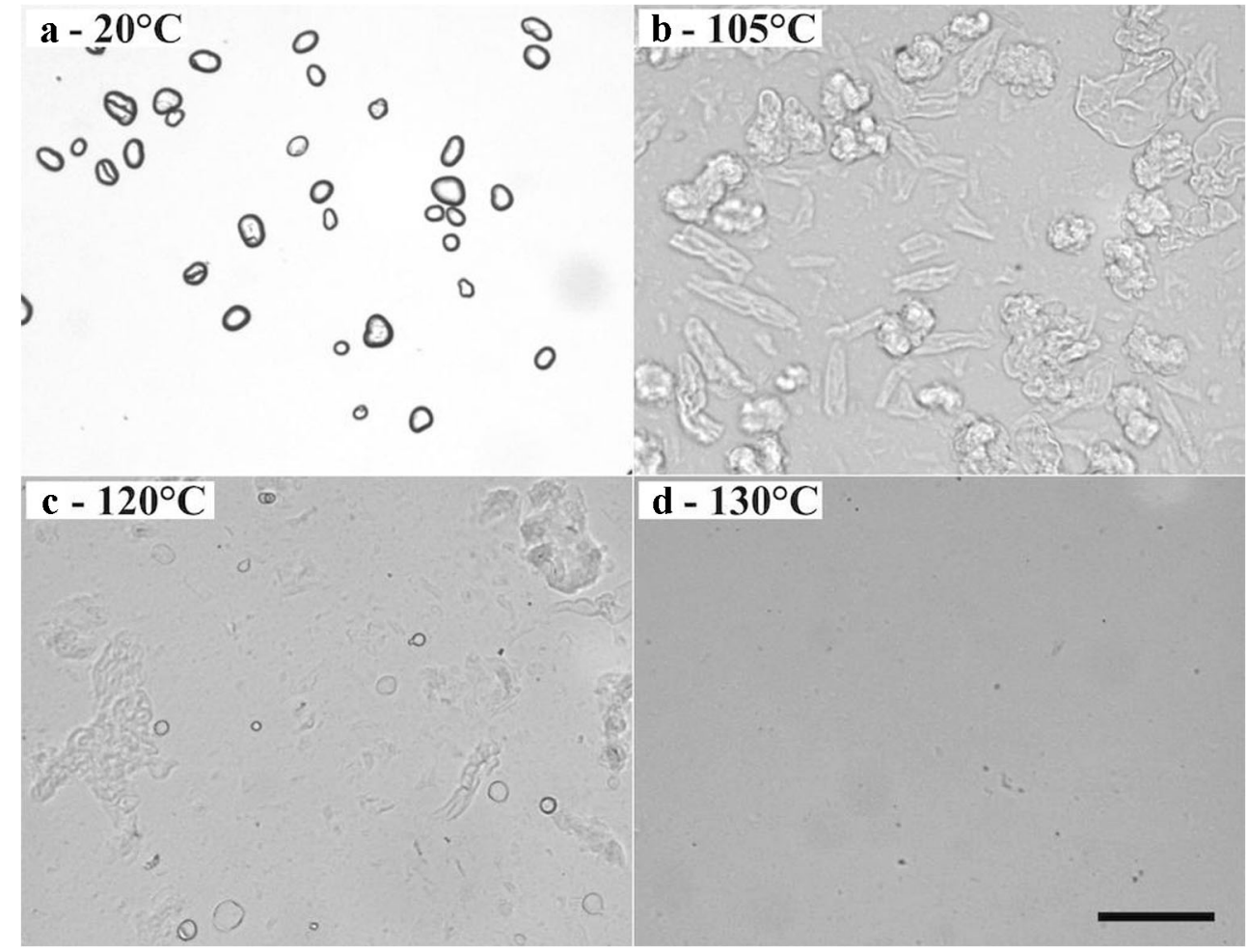


Fig. 6 Brown particles produced during the pasting of amylomaize starch, at 7 wt. $\%$ (a) and $10 \mathrm{wt} . \%$ (b) and under the microscope (cscale bar is $10 \mu \mathrm{m}$ )


possible, instead the granules swelled and retained their integrity (Fig. 4).

The pea starch granule presented intense swelling and lost their regular shape at 105 and $120^{\circ} \mathrm{C}$ and their complete dissolution could be achieved at $130^{\circ} \mathrm{C}$.

Debet et al. [32] analysed the starch granule remanants (also known as ghost particles) and found out that they can be composed of up to $10 \mathrm{wt} . \%$ of amylose. This amylose fraction, trapped in the starch granule remanant, is not involved in the $3 \mathrm{D}$ gel network formation. This fact corresponds well with our experiments in which it was observed that starch gels containing ghost particles deformed easily, presenting a strong plastic behaviour compared to the elastic, fully pasted starch gels.

Pasting the amylomaize starch suspensions above $135^{\circ} \mathrm{C}$ and for concentrations larger than $5 \mathrm{wt} . \%$ resulted in the formation of brown particles. These differed from the starch particle remanants (Fig. $4 \mathrm{~b}$ and $\mathrm{c}$ by their coloration but also by their aspect observed with the microscope (Fig. 6). Their presence and quantity varied as a function of the peak temperature reached during the pasting and also with the starch concentration. When the temperature was maintained under $135^{\circ} \mathrm{C}$ and for concentrations of $5 \mathrm{wt} . \%$ and below, no brown particles were observed.

Hot filtration was used to concentrate some of these brown particles, and elemental analysis has been performed to determine their nitrogen content in comparison to that of the pure starch. We assumed that all the nitrogen came from proteins,

Table 2 Nitrogen and protein content of the pea and amylomaize starch and of the brown particle rich gel of amylomaize starch

\begin{tabular}{lll}
\hline Sample & Nitrogen content [wt.\%] & Protein content [wt.\%] \\
\hline Particle rich material & 0.5 & 3.1 \\
Amylomaize starch & 0.080 & 0.50 \\
Pea starch & 0.051 & 0.32 \\
\hline
\end{tabular}

as neither starch nor eventual fatty acid contained in the starch granules have nitrogen in their structure. In accordance with the AOAC 2000 guidelines [33], the protein content was calculated by multiplying the nitrogen content by 6.25 (Table 2 ).

The brown particle rich material has a protein content (respectively nitrogen content) five times higher than the pure starch, demonstrating that the process by which they were formed, precipitated the protein rich material out of the bulk of the solution. This measurement and the temperature dependency for the brown particles formation supported the hypothesis that they were the product of Maillard reaction between the starch protein and the amylose or amylopectin during the pasting at temperature above $135^{\circ} \mathrm{C}$.

The pea starch has a lower protein content than the amylomaize, which could explain why it did not form such residues. Additionally, an older amylomaize batch from previous years did not produce such particles illustrating again the possible variability of the starch composition depending on the harvest.

Even though no apparent decrease in textural properties were observed when brown particles were not removed (data not included), the production of a precipitate in the initial



Fig. 7 Evolution of the shear viscosity of an amylomaize starch paste $\left(10\right.$ wt. \%) at a constant temperature $\left(80{ }^{\circ} \mathrm{C}\right)$ and constant shear rate $\left(1000 \mathrm{~s}^{-1}\right)$ 


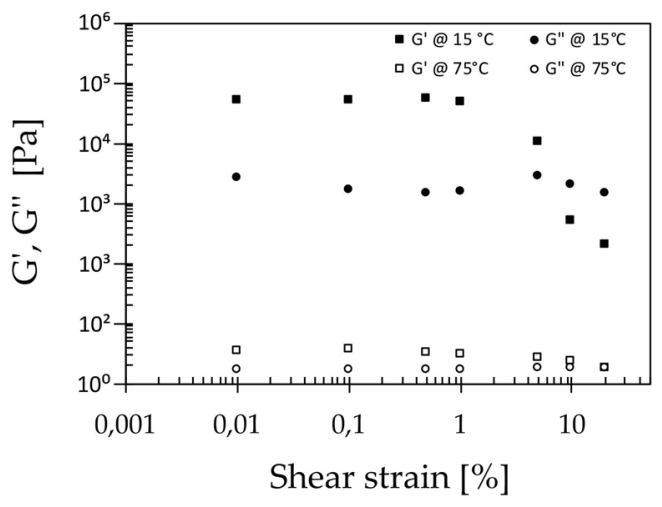

Fig. 8 Determination of the linear viscoelastic region (LVR) of two amylomaize system $(10 \mathrm{wt} . \%)$, at $15{ }^{\circ} \mathrm{C}$ (gel) and $75{ }^{\circ} \mathrm{C}$ (paste) with a shear strain sweep done at $1 \mathrm{~Hz}$

mixture is not desirable: it can be a source of fouling and can interfere with the emulsification process. This illustrates the importance of the initial starch characterization (in particular, for nitrogen content) to validate its compatibility with the pasting process. It also illustrates the possible effect of hot spots in the pasting device, which should be avoided by suitable operative measures.

\section{Gelation temperature}

Once the starch is fully dissolved in water after pasting, the gelation is triggered by reducing the temperature. Characterizing the gelation behaviour is critical to implement it into the particle production process. To this end, the starch pastes were studied with a rotational viscometer.

When the amylomaize starch paste viscosity was measured at constant temperature $\left(80^{\circ} \mathrm{C}\right)$ and constant shear rate $\left(1000 \mathrm{~s}^{-1}\right)$, it was observed that the apparent shear viscosity continuously increased from 27 to $33 \mathrm{mPa} . \mathrm{s}$ in about $40 \mathrm{~min}$ as depicted on Fig. 7. This showed that even at $80^{\circ} \mathrm{C}$ and under continuous shearing, there was a slow structure development (i.e. gelation) taking place.

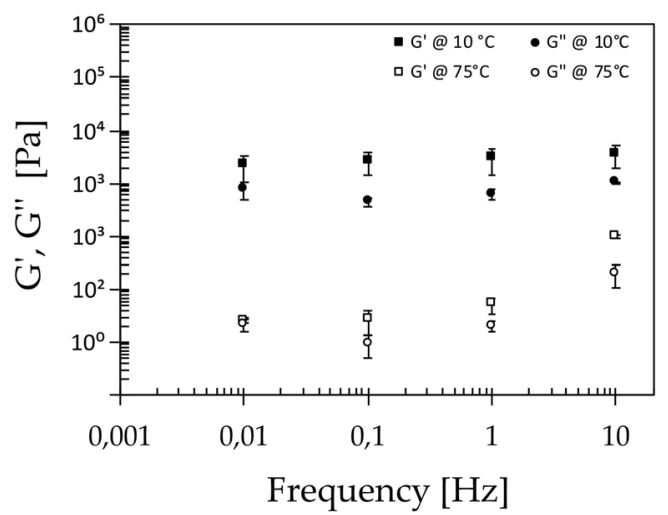

Fig. 9 Frequency sweep on two amylomaize systems ( $10 \mathrm{wt} . \%)$, at $10{ }^{\circ} \mathrm{C}$ (gel) and at $75{ }^{\circ} \mathrm{C}$ (paste) done with a shear strain of $0.1 \%$



Fig. 10 Evolution of the elastic ( $\left.\mathrm{G}^{\prime}\right)$ and viscous moduli (G') values during a temperature ramp from 80 to $10^{\circ} \mathrm{C}$ (cooling rate $1{ }^{\circ} \mathrm{C} / \mathrm{min}$ ) for amylomaize starch paste ( $7 \mathrm{wt} . \%)$ as it transitioned from a liquid-like paste to a gel. The graph $\mathrm{A}$ in the inset corresponds to the magnified region around the gelation point with the two linear fits

Using the oscillation mode of the rheometer, a shear strain sweep was done at constant frequency $(1 \mathrm{~Hz})$ for a starch paste at $75{ }^{\circ} \mathrm{C}$ that behaved macroscopically like a liquid and for a starch gel at $15^{\circ} \mathrm{C}$ (see Fig. 8). The elastic modulus (G') of the starch gel (at $15{ }^{\circ} \mathrm{C}$ ) decreased strongly above a shear strain of $1 \%$, delimiting the upper value of the linear viscoelastic region (LVR) in which oscillation can be used to characterized the gelation without damaging the gel structure. These first results were used to fix the shear strain to a value of $0.1 \%$ for the later experiments, allowing to record the elastic (G') and viscous moduli (G') of the starch system as it transition from a paste to a gel.

For the starch gel at $15{ }^{\circ} \mathrm{C}$, we observe that the elastic modulus is larger than the viscous modulus by a factor of about 100 , characteristic of a solid-like material. It is interesting to observe that at $75^{\circ} \mathrm{C}$, when the starch paste behaves macroscopically like a liquid, the elastic modulus was already larger than the viscous modulus, with a G'/G" ratio of about $1 / 2$. This is characteristic of a weak gel structure and confirms the structure development in the starch paste observed during the measurement of the apparent viscosity at $80^{\circ} \mathrm{C}$ shown in Fig. 7.

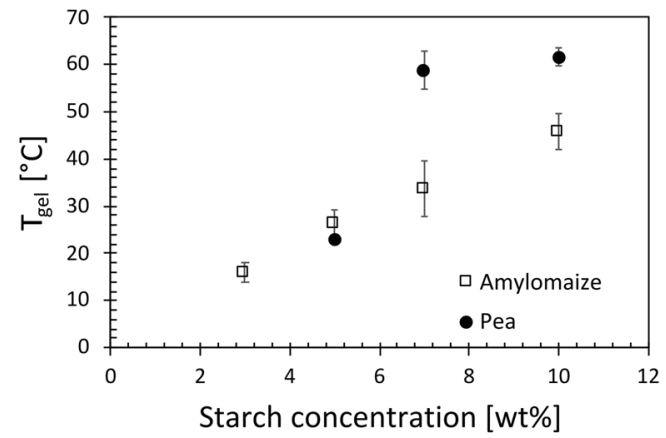

Fig. 11 Gelation temperature of pea and amylomaize starch paste at various concentrations 


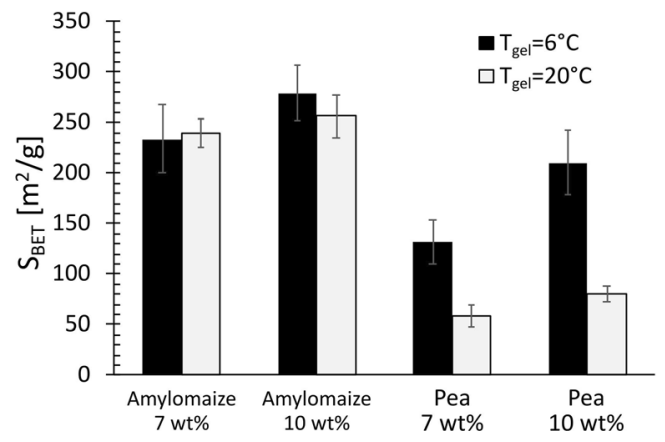

Fig. 12 Comparison of the specific surface area $\left(\mathrm{S}_{\mathrm{BET}}\right)$ of amylomaize and pea starch aerogels for two gelation/retrogradation temperatures (6 and $20{ }^{\circ} \mathrm{C}$ ) and two concentrations (7 and $\left.10 \mathrm{wt} . \%\right)$

These results demonstrated that once the temperature is decreased after the pasting, the starch paste is no longer stable and its rheological behaviour changes with time, even if the temperature is kept constant at $80-90^{\circ} \mathrm{C}$. This is of significant importance if the starch paste is to be processed with the emulsion gelation method, as the viscosity is critical to control the particle size distribution.

A frequency sweep was also done at a fixed shear strain of $0.1 \%$ for a gel at $10{ }^{\circ} \mathrm{C}$ and a paste at $75{ }^{\circ} \mathrm{C}$ (Fig. 9). As expected, the gel's $\mathrm{G}^{\prime}$ and G" displayed little sensitivity to the frequency, but the paste did behave like a liquid with increased G' and G' at higher frequency [34].

The determination of the gelation temperature of the starch pastes was done by loading the pastes at $80{ }^{\circ} \mathrm{C}$ in the rheometer and recording the $\mathrm{G}^{\prime}$ and $\mathrm{G}^{\prime}$ ' evolution $(0.1 \%$ strain and $1 \mathrm{~Hz}$ frequency) with a cooling rate of $1{ }^{\circ} \mathrm{C} / \mathrm{min}$. Typical result of these experiments is shown in Fig. 10, where the elastic modulus increases in an accelerating manner with the decreasing temperature. Because G' was always above G', no crossover point could be used to determine the gel point. Instead, two linear fits on the $\mathrm{G}^{\prime}$ curve were done for the $80-70^{\circ} \mathrm{C}$ and $37-22{ }^{\circ} \mathrm{C}$ temperature ranges (red dashed lines in Fig. 10), where the $\mathrm{G}^{\prime}$ rate of changes were respectively the smallest $\left(-0.204 \mathrm{~Pa} /{ }^{\circ} \mathrm{C}\right)$ and the largest $\left(-3750 \mathrm{~Pa} /{ }^{\circ} \mathrm{C}\right)$. The gelation temperature was then determined by finding the intersection of the two linear fits (blue point in Fig. 10). The resulting

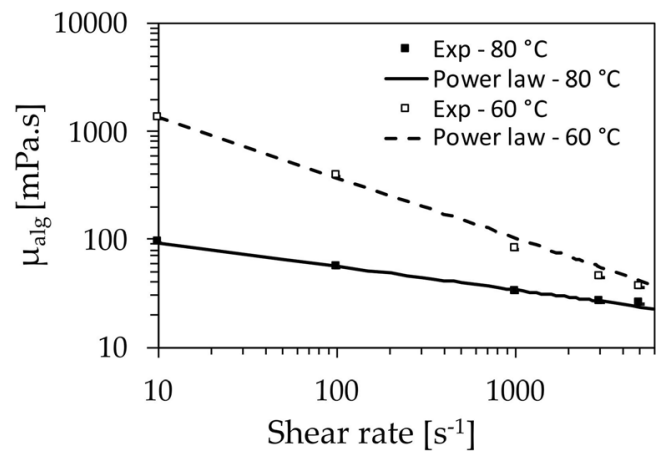

Fig. 13 Amylomaize starch paste (10 wt. \%) viscosity measurement at 80 and $60{ }^{\circ} \mathrm{C}$

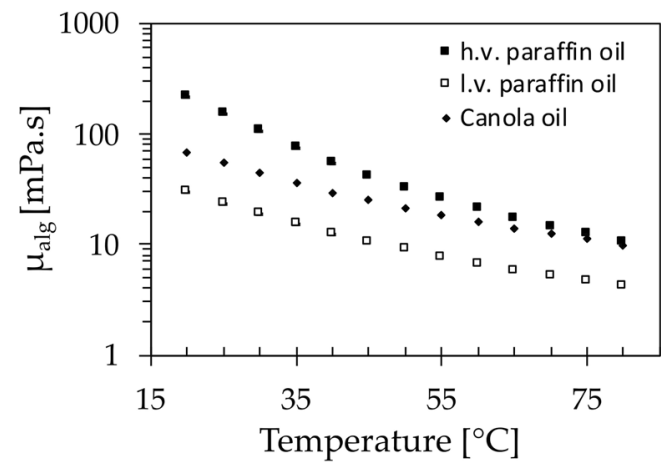

Fig. 14 Viscosities of the low-viscosity (l.v.) and high-viscosity (h.v.) paraffin oils and rapeseed oil at $15-80{ }^{\circ} \mathrm{C}$ measured at a shear rate of $1000 \mathrm{~s}^{-1}$

gelation temperatures for pea and amylomaize starches ( 3 to $10 \mathrm{wt} . \%$ for) can be observed in Fig. 11.

For both starch types, as the concentration increased, the gelation temperature also increased. With the amylomaize starch, the increase was linear but for the pea starch a clear step can be observed between 5 and $7 \mathrm{wt} . \%$ and not much of a difference between 7 and $10 \mathrm{wt} . \%$. This step gave the pea starch at 7 and $10 \mathrm{wt} . \%$ a significantly higher gelation temperature than the amylomaize starch.

\section{Retrogradation and solvent exchange}

Once the starch gels are formed, the gel network further developed with time during the so-called retrogradation step. We carried it at both $6{ }^{\circ} \mathrm{C}$ and at room temperature to evaluate how it influences the surface area $\left(\mathrm{S}_{\mathrm{BET}}\right)$ of the final starch aerogels.

Suspensions of pea and amylomaize starch were pasted at $130{ }^{\circ} \mathrm{C}$ and $140{ }^{\circ} \mathrm{C}$, respectively, poured into moulds and either allowed to gel and retrograde at room temperature or at $6{ }^{\circ} \mathrm{C}$ for 24 to $48 \mathrm{~h}$. The gel monoliths were then solvent exchanged to reach ethanol concentrations from 95 to $99 \mathrm{wt} . \%$ and supercritically dried. No significant effect of the end concentration of ethanol in this range could be observed; their BET surface areas were thus averaged and plotted on Fig. 12.

For the amylomaize starch, no significant effect of the gelation temperature could be observed, making the gelation and retrogradation at lower temperature optional at such concentration. For the pea starch on the other hand, the effect of the gelation temperature was significant and the SBET of the

Table 3 Parameters for the power law fit of the amylomaize starch paste (10 wt.\%) apparent viscosity at 80 and $60{ }^{\circ} \mathrm{C}$

\begin{tabular}{lll}
\hline Temperature $\left[{ }^{\circ} \mathrm{C}\right]$ & $K$ & $n$ \\
\hline 80 & 0.156 & 0.78 \\
60 & 4.94 & 0.43 \\
\hline
\end{tabular}




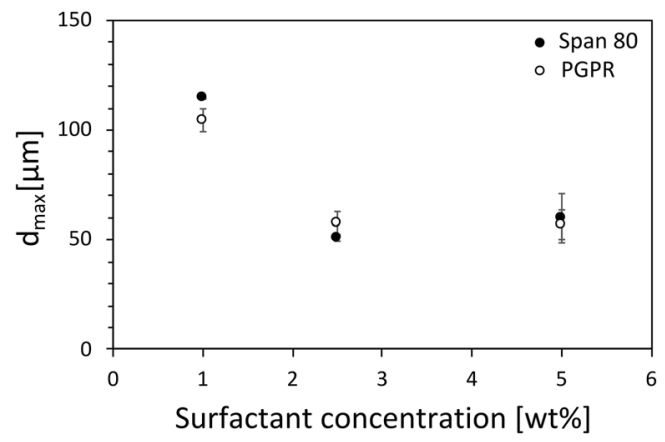

Fig. 15 Largest stable drop as a function of the surfactant concentration (Span80 - filled black circles and PGPR - empty circles) at 1050 RPM with the FBT

sample gelled at room temperature were half of the ones gelled at $6{ }^{\circ} \mathrm{C}$.

Leloup et al. showed that the starch gel structure is composed of fibrils about $20 \mathrm{~nm}$ in diameter with a mesh size (distance between fibrils) of about $100 \mathrm{~nm}$ [35]. These fibrils are composed of amylose crystal presenting a characteristic B-type Xray diffraction pattern corresponding to their double helix structure. Garcia-Gonzalez et al. observed the same characteristic Xray diffraction pattern for starch aerogel [19] along with our results indicating a similar fibril structure in starch aerogel SEM pictures [36]. Lu et al. studied the retrogradation of potato amylose at different temperatures and showed that after $24 \mathrm{~h}$, only $13 \%$ of amylose retrograded at $25{ }^{\circ} \mathrm{C}$ compared with $60 \%$ at $5{ }^{\circ} \mathrm{C}$ [37]. The temperature thus plays an important role in the formation of the crystalline structure of the starch gel which translates in the textural properties of resulting starch aerogels. The reason that such an effect was not observed for amylomaize

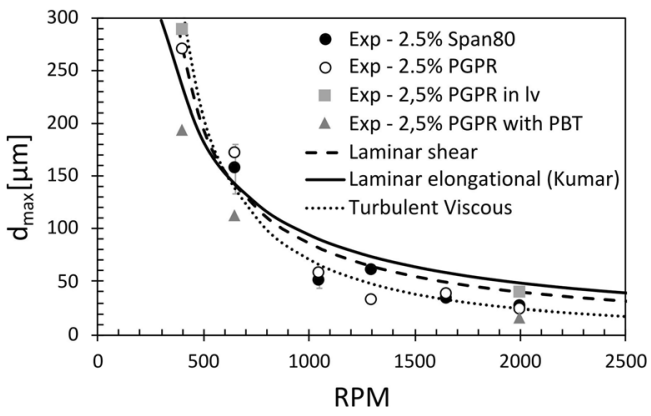

Fig. 17 Variation of the largest droplet size in the emulsion as a function of the stirring speed in the stirred vessel. Black circles correspond to 2.5 wt.\% Span 80 in high-viscosity paraffin oil with the FBT, white circles to $2.5 \mathrm{wt}$.\% PGPR in high-viscosity paraffin oil with the FBT, grey triangles to $2.5 \mathrm{wt}$.\% PGPR in high-viscosity paraffin oil with PBT and grey squares with $2.5 \mathrm{wt} . \%$ PGPR in low-viscosity oil with the FBT. The dashed line corresponds to the pure shear model with fitted IFT of $0.8 \mathrm{mN} / \mathrm{m}$, the plain line represents the pure elongational model with fitted IFT of $19.9 \mathrm{mN} / \mathrm{m}$ and the dotted line - the turbulent viscous model with fitted IFT of $4.4 \mathrm{mN} / \mathrm{m}$

starch could lie in the difference of amylose concentration between the two starches (66\% vs. $45 \%$ ).

For the same starch concentration, the amylomaize starch produced aerogel with higher surface area compared to the pea starch. The amylomaize starch has a significantly higher amylose content than the pea starch, which allows it to form aerogel with better textural properties as already discussed by Druel et al. [20].

Mehling et al. [14] obtained $S_{\mathrm{BET}}$ of $90 \mathrm{~m}^{2} / \mathrm{g}$ using high amylose corn starch Eurylon7 (similar to amylomaize used in this study) pasted at $95{ }^{\circ} \mathrm{C}$ and described a low mechanical stability. That can be attributed

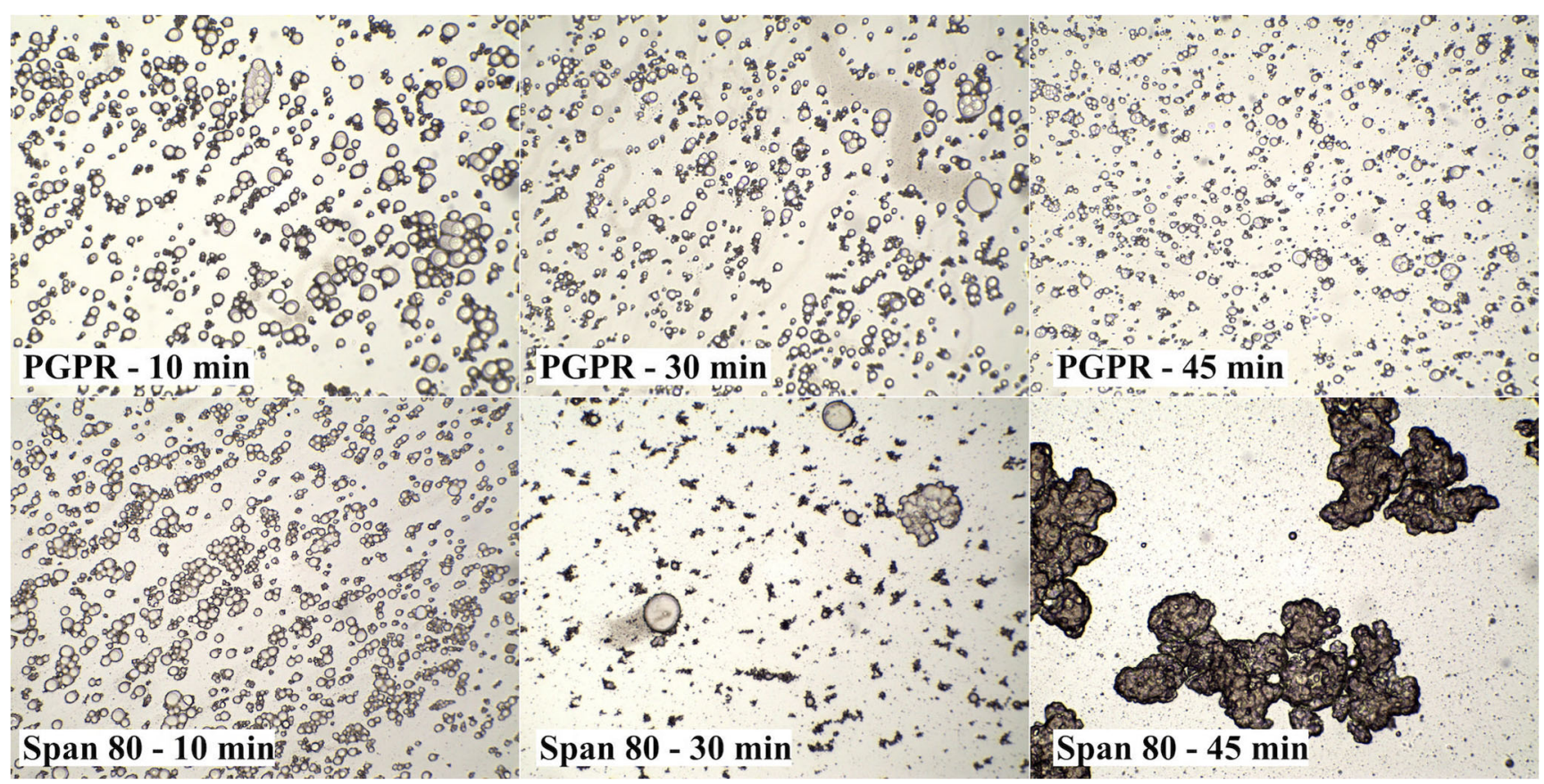

Fig. 16 Amylomaize starch gel microparticle suspensions produced by emulsion gelation in stirred tank with Span80 and PGPR for stirring time of 10, 30 and $45 \mathrm{~min}$ 


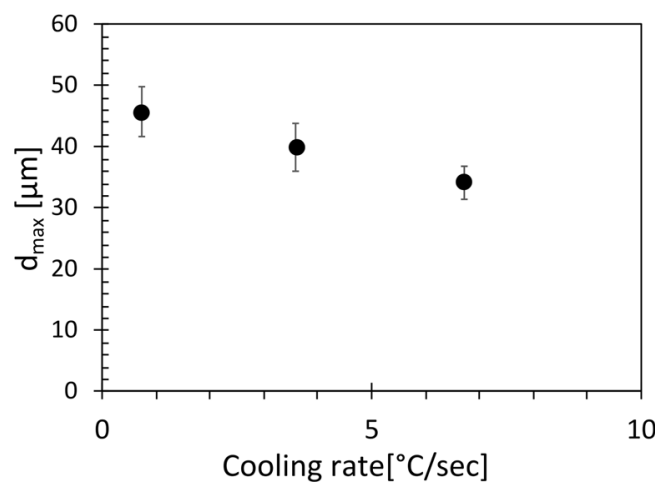

Fig. 18 Effect of the cooling rate during the gelation in emulsion on the gel microparticle diameter

to the incomplete pasting occurring at such temperatures, illustrating the importance of complete starch granule dissolution for the formation of strong starch gels and starch aerogels with good textural properties.

The pea and amylomaize starch aerogels produced in this study gave similar surface area as the one produced by Druel et al. [20] (respectively $221 \mathrm{~m}^{2} / \mathrm{g}$ and $254 \mathrm{~m}^{2} / \mathrm{g}$ from $8 \mathrm{wt} . \%$ starch suspensions) or by Garcia-Gonzalez et al. [19] (204$230 \mathrm{~m}^{2} / \mathrm{g}$ at 5-15 wt.\%). However, Kenar's [21] starchsodium palmitate complexes were having significantly higher surface area $\left(362 \mathrm{~m}^{2} / \mathrm{g}\right.$ at $\left.5.5 \mathrm{wt} . \%\right)$.

\section{Emulsion gelation}

Viscosities of continuous and dispersed phases of an emulsion are critical parameters in the determination of the emulsion droplet size. The viscosity of the starch paste was measured at 80 and $60^{\circ} \mathrm{C}$ (Fig. 13), and the viscosities of the different oils used for the emulsification (high- and low-viscosity paraffin oils and rapeseed oil) were measured in the $15-80{ }^{\circ} \mathrm{C}$ temperature range (Fig. 14).

The oils presented a Newtonian behaviour and no dependency on the shear rate could be observed. On the other hand, the starch paste demonstrated a strong shear thinning behaviour that is well described by a power law fit (Eq. 1); parameters can be found in Table 3 .

$\mu_{\text {diss, app }}=K \dot{\gamma}^{n-1}$

\section{Emulsifier type and concentration}

The concentration of surfactant was varied during the emulsification from 1 to $5 \mathrm{wt} . \%$ for both PGPR and Span80. As depicted on Fig. 15, the effect of both surfactants was similar, with an effective particle size reduction as the concentration was increased from 1 to $2.5 \mathrm{wt} . \%$. No further particle size reduction was observed when increasing the surfactant concentration to $5 \mathrm{wt} . \%$.

However, when the emulsification duration was increased, it was observed that the Span 80 triggered an early gelation and agglomeration of the starch paste droplets when kept at $80^{\circ} \mathrm{C}$ under stirring. Agglomerates begun to form after $30 \mathrm{~min}$ and the emulsion collapsed into large agglomerates after $45 \mathrm{~min}$ (Fig. 16). Ortega-Toro et al. reported amylose complexation with several Span surfactants (40,60 and 80) [38] which matched our observations. PGPR did not exhibit such an effect and no agglomeration could be observed after $45 \mathrm{~min}$ (Fig. 16).

Thus, if the emulsification time is prolonged (e.g. emulsification in larger batches), the type of the surfactant used can be decisive. In our case, Span 80 cannot be considered as a reliable surfactant for such cases.

\section{Batch wise emulsification: stirred vessel}

The stirring speed was varied from 400 to 2000 RPM with the FBT using both Span 80 and PGPR at 2.5 wt.\% in highviscosity paraffin oil (black and white circles on Fig. 17). As the emulsification time was $10 \mathrm{~min}$, no agglomeration was observed with the Span80, and the particle size obtained with the two surfactants was not significantly different. With the variation of stirring speed, the particle size could be controlled between 270 and $25 \mu \mathrm{m}$.

For these experiments, the impeller Reynolds number varied from 280 to 1450 , corresponding to the transitional range between laminar and turbulent regime. Several expressions for the largest stable drop diameter in an emulsion are available in the literature. As we are neither fully laminar nor fully turbulent, three expressions corresponding to three different idealized flow types were evaluated:

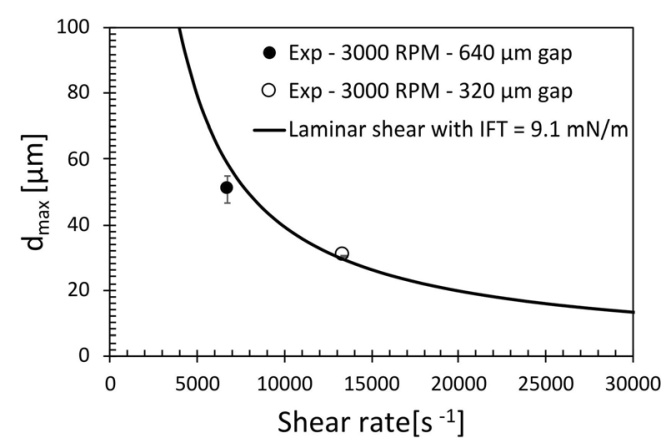

Fig. 19 Variation of the droplet size during the emulsification of the starch paste with the colloid mill as a function of the shear rate. The emulsification was done in high-viscosity paraffin oil with $2.5 \mathrm{wt}$ \% PGPR. The black line represents the estimated largest droplet size in the emulsion obtained from the critical shear capillary number $\left(\mathrm{d}_{\max }=2 \mathrm{Ca}_{\text {crit }}^{\mathrm{e}} \sigma / \mu_{\mathrm{em}} \dot{\gamma}\right)$ with a fitted IFT of $9.1 \mathrm{mN} / \mathrm{m}$ 



Fig. 20 Amylomaize starch (7 wt.\%) gel microparticles produced with the emulsification carried out at $90{ }^{\circ} \mathrm{C}$ with $0.5 \mathrm{wt} . \%$ PGPR in rapeseed oil at $20 \mathrm{v} \%$ (heat exchanger outlet measured at $37^{\circ} \mathrm{C}$ ). The scale bars correspond to $200 \mu \mathrm{m}$ for A and to $80 \mu \mathrm{m}$ for B

a. Laminar shear (Couette flow) with Eqs. 2 and 3 from de Bruijn [39]

$d_{\max }^{s}=\frac{2 C a_{\text {crit }} \sigma}{\mu_{e m} \dot{\gamma}}$

$\log _{10} C a_{c r i t}^{s}=-0.506-0.0994 \log _{10} \lambda$

$$
+0.124\left(\log _{10} \lambda\right)^{2}-\frac{0.115}{\log _{10} \lambda-\log _{10} 4.08}
$$

b. Turbulent viscous with Eq. 4 from Kolmogorov [31]

$d_{\max , T V}=A_{2} \epsilon_{\max }^{-1 / 2} \mu_{\text {cont }}^{-1 / 2} \rho_{\text {cont }}^{-1 / 2} \sigma$

c. Laminar extensional (2D hyperbolic flow) with Eqs. 5 and from Hinch [40] $d_{\max }^{e}=\frac{2 C a_{c r i t}^{e} \sigma}{\mu_{e m} \dot{\epsilon}}$

$C a_{c r i t}^{e}=\frac{0.15}{\lambda^{1 / 6}}$

In Eqs. 3 and 6, $\lambda$ refers to the viscosity ratio of the two emulsion's phase $\left(\lambda=\mu_{\text {disp }} / \mu_{\text {cont }}\right)$, and $\epsilon_{\max }$ in Eq. 4 is the maximal energy dissipation rate, which can be expressed according to Eq. $7[41,42]$.

$\epsilon_{\text {max }}=\frac{P_{\text {imp }}}{V_{\text {swept }} \rho_{\text {cont }}}=\frac{N p N^{5} D_{\text {imp }}^{2}}{\left(D_{\text {imp }}^{2} / 4\right) h_{\text {imp }} \rho_{\text {cont }}}$

If one assumes the droplet break-up to be controlled by a pure shear break-up model (a), the largest stable drop in emulsion can be estimated with Eq. 2 (dashed line in Fig. 17). The maximal shear rate, estimated using Bowen's equation [43] (Eq. 8), was used to calculate the apparent viscosity of the starch melt with the power law model parameters described in Table 3 .

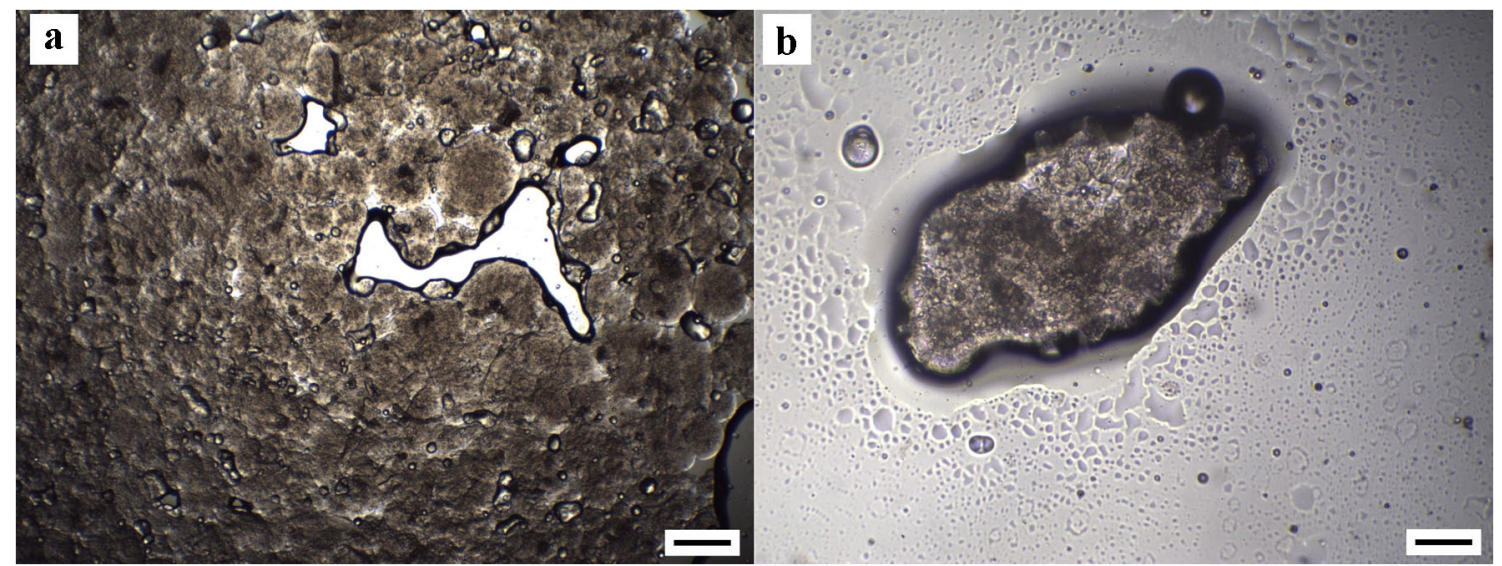

Fig. 21 Amylomaize starch (7 wt.\%) gel microparticles produced with the emulsification carried out at $90{ }^{\circ} \mathrm{C}$ without surfactant in rapeseed oil at $20 \mathrm{v} \%$ (heat exchanger outlet measured at $35^{\circ} \mathrm{C}$ ). The scale bars correspond to $200 \mu \mathrm{m}$ for both $\mathrm{A}$ and $\mathrm{B}$ 


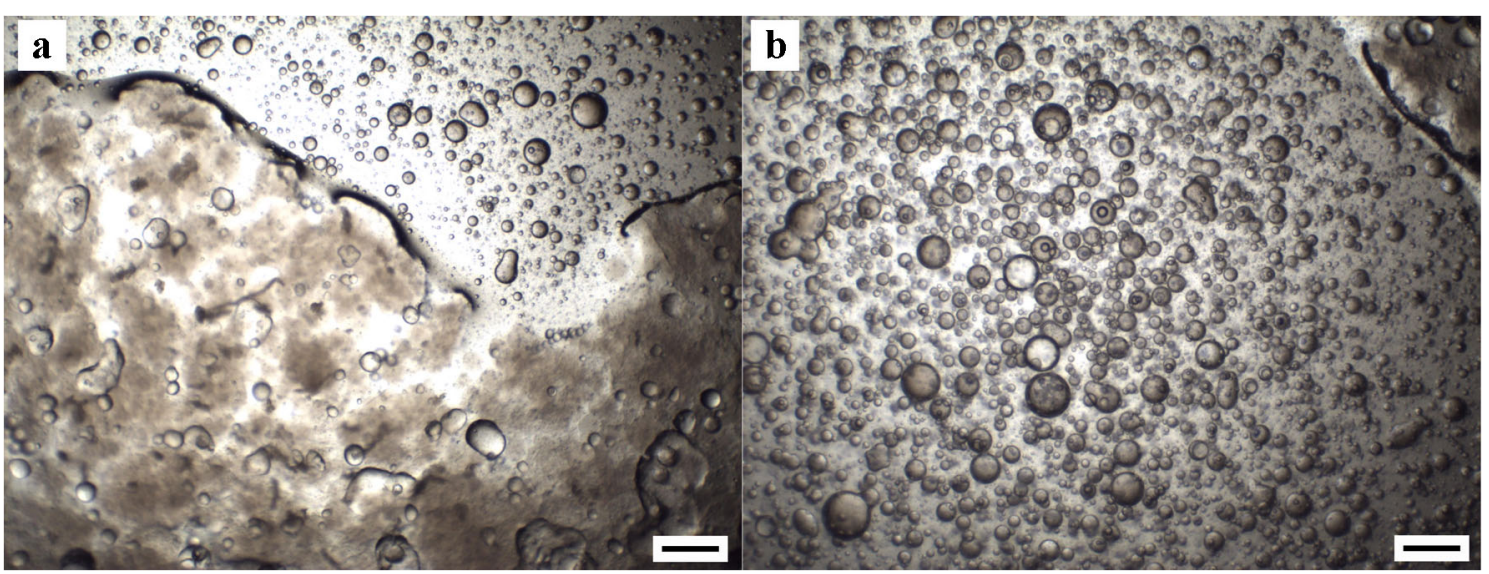

Fig. 22 Amylomaize starch $(7 \mathrm{wt} . \%)$ gel microparticles produced with the emulsification carried out at $90{ }^{\circ} \mathrm{C}$ with $0.5 \mathrm{wt} . \%$ PGPR in rapeseed oil at $33 \mathrm{v} \%$ (heat exchanger outlet measured at $35^{\circ} \mathrm{C}$ ). The scale bars correspond to $200 \mu \mathrm{m}$ for both A and B

$\gamma_{\max }=9.7 N\left(\frac{d_{\text {imp }}}{d_{\text {tank }}}\right)^{0.3} \frac{d_{\text {imp }}}{W}$

The shear critical capillary number was calculated with de Bruijn equation (Eq. 3), considering the apparent viscosity of the starch melt for the dispersed phase and the viscosity of the emulsion calculated with the equation from Yaron and Gal-Or [44] (Eq. 9) to calculate the apparent viscosity ratio (Eq. 10).

$\mu_{\text {em }}=\mu_{\text {cont }}\left(1+\frac{5.5 \Phi\left(4 \Phi^{7 / 3}+10-\frac{84}{11} \Phi^{2 / 3}+\frac{4}{\lambda}\left(1-\Phi^{7 / 3}\right)\right)}{10\left(1-\Phi^{10 / 3}\right)-25 \Phi\left(1-\Phi^{4 / 3}\right)+\frac{10}{\lambda}(1-\Phi)\left(1-\Phi^{7 / 3}\right)}\right)$

$\lambda_{\text {app }}=\frac{\mu_{\text {disp }, a p p}}{\mu_{e m}}$

The IFT was fitted to the experimental data and even though this approach provided a good description of the particle size, it required an IFT value of $0.8 \mathrm{mN} / \mathrm{m}$. Such value is not realistic considering that the water-paraffin oil system has an IFT of $55 \mathrm{mN} / \mathrm{m}$ and that the water-paraffin-Span80 $1 \mathrm{wt} . \%$ oil system has an IFT of $2.3 \mathrm{mN} / \mathrm{m}$ after $2500 \mathrm{~s}$ at $20^{\circ} \mathrm{C}[24]$. Additionally, as it was discussed by Baudron et al. [24], the relevant IFT during the emulsification is larger than the measured equilibrium IFT values, further discrediting such small fitted IFT. With such considerations, we concluded that the droplet break-up did not occur only from a pure shear flow, which is expected in a stirred vessel with such Reynolds number. Nonetheless, Baudron et al. [24] showed that this approach yields better results for the emulsification of alginate solutions in paraffin oils at room temperature and with lower Reynolds number.

Even though the flow regime is not fully turbulent, the turbulent viscous model of Kolmogorov (b) was tested (dotted line in Fig. 17) to continue the investigation on the droplet break-up mechanism. It yielded a reasonable fit and description of the experimental data with an IFT value of $4.4 \mathrm{mN} / \mathrm{m}$. To further confirm such description, further experiments with a PBT (represented as grey triangles on Fig. 17) were carried out, and smaller particles were produced at the same stirring rate. Additionally the oil viscosity was varied (represented as grey squares on Fig. 17), and only little effect on the particle size could be observed.

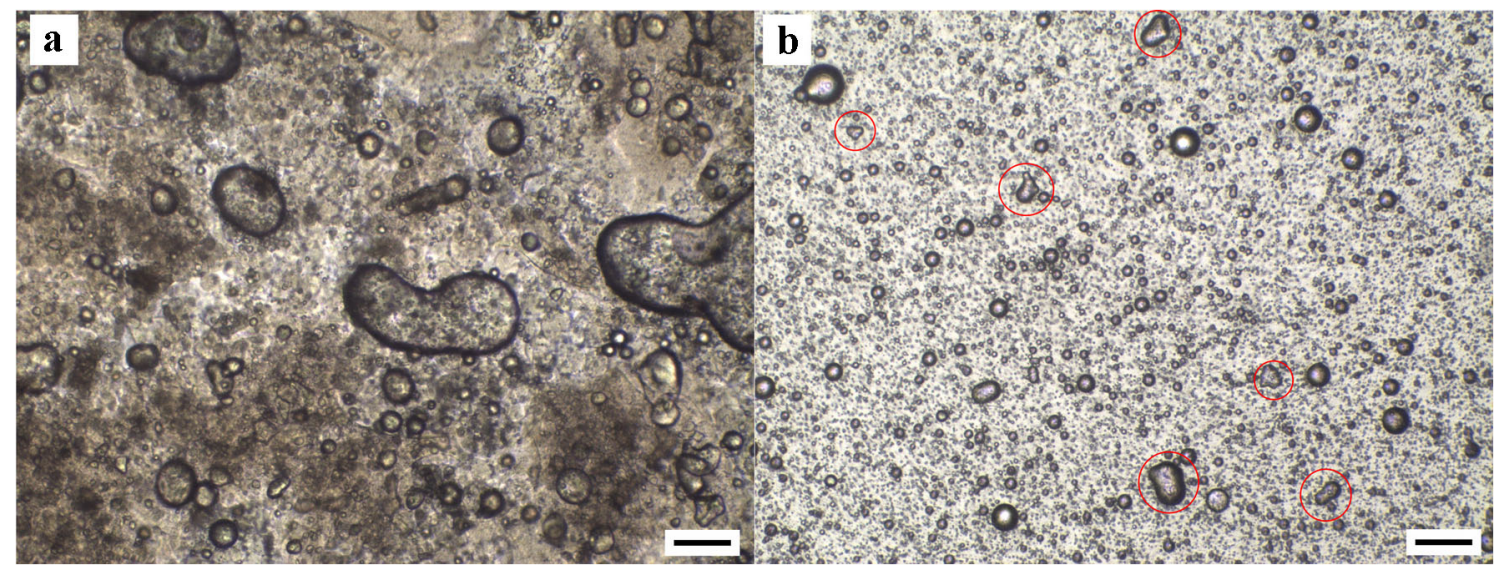

Fig. 23 Worst-case scenario - gelation without cooling (amylomaize starch 7 wt. \%). The scale bars correspond to $200 \mu \mathrm{m}$ for A and $80 \mu \mathrm{m}$ for B 


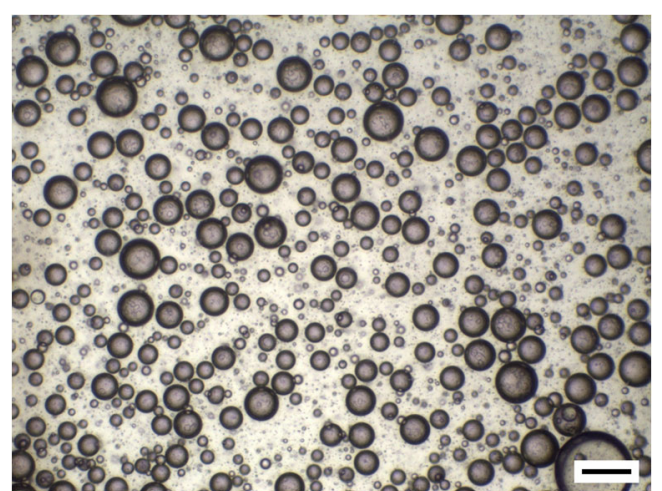

Fig. 24 Amylomaize starch (7 wt.\%) gel microparticles produced with the emulsification carried out at $80{ }^{\circ} \mathrm{C}$ with $0.5 \mathrm{wt} . \%$ PGPR surfactant in rapeseed oil at $20 \mathrm{v} \%$ (heat exchanger outlet measured to be $32^{\circ} \mathrm{C}$ ). The scale bar corresponds to $80 \mu \mathrm{m}$

The FBT has a higher power number than the PBT [45] resulting in higher energy dissipation rate at the same stirring speed. If the break-up occurred in the turbulent viscous regime, the FBT should result in smaller particle size but the opposite is observed experimentally. Similarly, the model forecasts larger particle size with a lower continuous phase viscosity, but again no such effect was observed. These two supplementary sets of experiments confirmed that the droplet break-up cannot be represented properly with the turbulent viscous model.

Wille et al. [46] described the effect of macroscopic elongational flow on the emulsification in stirred tank. They showed that axial flow impellers yielded smaller droplets than their radial counterparts. With particle image velocimetry (PIV), they also observed larger macroscopic elongational flow produced by the axial flow impeller and concluded that this flow type played a crucial role in the droplet break-up. Such results matched well our observations and hinted that the droplet break-up in our system seemed to be more influenced by the elongational flow produced by the impeller.

Kumar et al. [47] proposed an approach to estimate the elongational rate in the vicinity of a radial flow impeller and

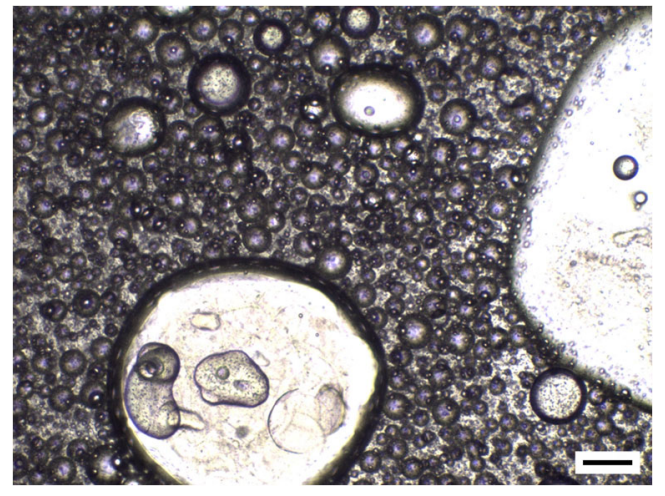

Fig. 25 Pea starch gel microparticles produced with the emulsification carried out at $90{ }^{\circ} \mathrm{C}$ with $0.5 \mathrm{wt} . \%$ PGPR in rapeseed oil at $50 \mathrm{v} \%$ (heat exchanger outlet measured at $35^{\circ} \mathrm{C}$ ). The scale bar corresponds to $80 \mu \mathrm{m}$ used it to describe the droplet break-up in elongational flows. Using their expression for the average elongational rate in the hyperbolic flow produced in the vicinity of the impeller (Eq. 11, with $\bar{f}=7.8$ ) and the expression of the elongational critical capillary number $\mathrm{Ca}_{\text {crit }}^{e}$ proposed by Hinch [40] (Eq. 5), the size of largest stable drop in such flow field was estimated (plain line in Fig. 17) with a fitted IFT value of $19.9 \mathrm{mN} / \mathrm{m}$.

$\dot{\epsilon}=6 \pi N \bar{f}$

This approach provides a good description of the droplet break-up with a reasonable IFT value, but the estimation is, however, not perfect, and a clear overestimation of the droplet size can be observed at higher stirring speeds. This is expected from the simplistic approach used to estimate the elongational rate but could be improved with PIV measurement or CFD simulation.

The flow in a stirred vessel is complex and heterogeneous, especially with a viscous continuous phase. We demonstrated that using models that only considers pure flow type (pure shear, pure elongational or turbulent) did not allow for a fully quantitative description of the droplet break-up in our system. We demonstrated in a previous work (Baudron et al. [24]) that the pure shear approach from de Bruijn could yield a good description of the emulsification in a similar set-up but operating at lower Reynolds number. This is consistent with the laminar flow assumption of this model that was not fully fulfilled in the present work. The elongational component of the flow seems to play the most important role in these flow conditions which the turbulent break-up approach could not properly represent.

In order to increase the production rate of starch gel particles, a semi-continuous approach can also be considered. The use of a colloid mill allows for the processing of the starch melt emulsion in a semi-continuous mode, i.e. to process larger quantities without changing the geometry of the emulsification device.

\section{Batch wise gelation in emulsion: stirred vessel}

To investigate the effect of the cooling rate on the particle size distribution during the batch emulsification, three cooling rates were investigated: Three emulsifications were carried out (FBT at 1050 PRM in high-viscosity paraffin oil with $2.5 \mathrm{wt} . \%$ PGPR) and cooled down to $20^{\circ} \mathrm{C}$ while maintaining stirring (400 RPM) with a water bath at $6{ }^{\circ} \mathrm{C}$, a water bath at $20^{\circ} \mathrm{C}$ and in air at $20^{\circ} \mathrm{C}$, resulting in cooling rates of $6.7,4.6$ and $0.7^{\circ} \mathrm{C} / \mathrm{s}$, respectively.

The particle sizes of the suspensions produced from the cooling of these three emulsions are displayed in Fig. 18. A significant effect of the cooling rate can be observed on the 
Fig. 26 Amylomaize starch aerogel (7 wt.\%) microparticles produced with the emulsion gelation method. The scale bars correspond to $40 \mu \mathrm{m}$ for $\mathrm{A}$ and $10 \mu \mathrm{m}$ for $\mathrm{B}$
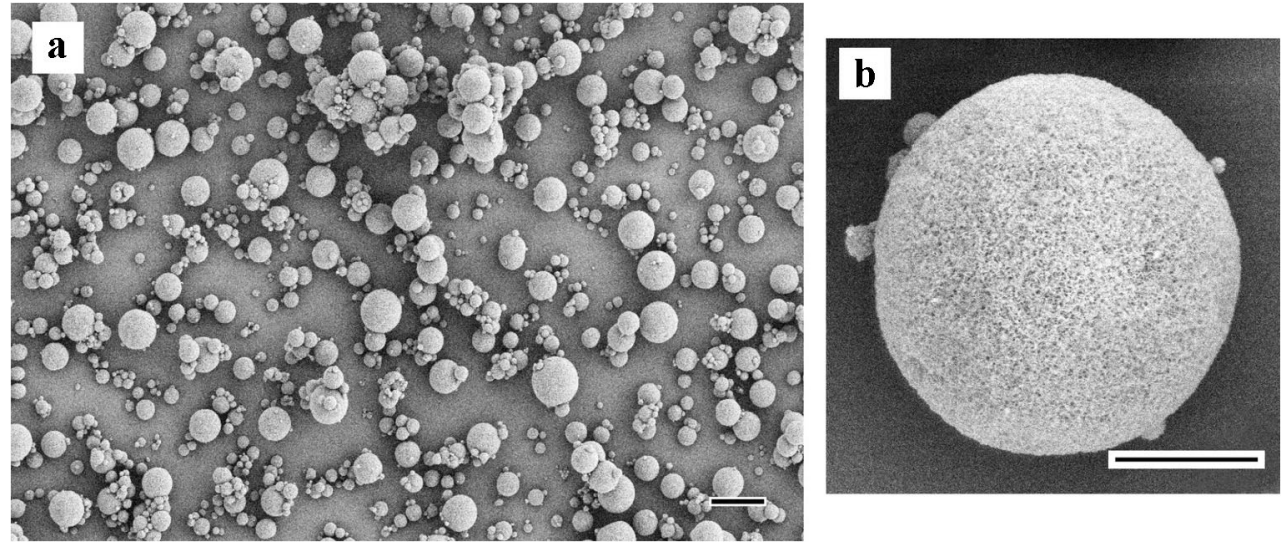

final particle size, demonstrating that even with surfactant, some coalescence events can occur during slower gelations.

\section{Semi-continuous emulsification: colloid mill}

Colloid mills are emulsification devices commonly used in the industry for the processing of viscous systems. We investigated the emulsification of the starch paste in such a device for two shear rates by keeping the stirring speed constant at 3000 RPM and variating the gap between the rotor and the stator from 640 to $320 \mu \mathrm{m}$. In only one pass, particles with $\mathrm{d}_{\max }$ between 30 and $50 \mu \mathrm{m}$ were produced as represented in Fig. 19.

The Reynolds number in colloid mills can be calculated according to Eq. 12 [48] and was between 19 and 36 for this system, characterizing a laminar flow [49].

$\operatorname{Re}_{C M}=\frac{\rho \omega r_{i} \delta}{\mu_{e m}}$

where $\delta$ is the gap in the colloid mill. We used the pure shear critical capillary number from de Bruijn (Eq. 2), similarly to what was done previously for the stirred vessel to estimate the largest stable drop in the emulsion (plain line in Fig. 19), and used Eq. 13 for the shear rate estimation.

$\dot{\gamma}=\frac{\pi d \omega}{\delta}$

The pure shear model described well the experimental values, and a reasonable fitted IFT value of $9.1 \mathrm{mN} / \mathrm{m}$ was obtained. In this case, the laminar regime determined by the Reynolds number and the flow dominated by shear made this simple model a reliable description of the droplet break-up.

\section{Semi-continuous gelation in emulsion: heat exchanger (HE)}

In addition to the advantage the well-defined laminar regime, the colloid mill can be operated semi-continuously allowing the processing of larger quantities without changing the scale of the emulsification device. Semi-continuous operation with the set-up depicted in Fig. 3 was realized, and gelation was achieved in-line in a coaxial heat exchanger.

As soon as the emulsion escapes the colloid mill, no further droplet break-up takes place because of the low shear in the piping, and as a result, the droplet size can increase through coalescence (ideally mitigated by the presence of surfactant). The colloid mill outlet also corresponds to the beginning of the emulsion cooling that trigger the gelation of the starch melt droplets. It is clear that once the starch droplets are gelled, no further coalescence can happen. Ideally, the droplets should gel as fast as possible in order to hinder coalescence and obtain the smallest gel particles possible.

The final particle size is influenced by the coalescence and gelation rate. To explore experimentally such a relationship, a reference experiment was carried out, and the resulting particles were compared with the ones from two experiments. The following parameters were varied in the latter experiments one after another:

- The surfactant and phase ratio were varied to influence the coalescence rate.

- The starch type, cooling or emulsification temperature was varied to influence the gelation rate.

The emulsification of amylomaize starch paste $(7 \mathrm{wt} . \%)$ at $90{ }^{\circ} \mathrm{C}$ with $0.5 \mathrm{wt} . \%$ PGPR in rapeseed oil, with a phase ratio of $20 \mathrm{v} \%$ in a one pass through the colloid mill (3000 RPM $636 \mu \mathrm{m}$ gap), was chosen as the reference experiment. The emulsion was cooled in the heat exchanger and discharged in an unstirred vessel. At such conditions, large agglomerates, several hundreds of micrometres across, were produced (Fig. 20a) together with many round microparticles (Fig. 20b). The presence of agglomerates is the sign of partial coalescence and the result of an insufficient gelation rate. The temperature of the emulsion at the heat exchanger outlet was measured to be $37^{\circ} \mathrm{C}$, which falls in the range of the gelation temperature for this system $\left(34 \pm 5{ }^{\circ} \mathrm{C}\right.$; see Fig. 10). This implies that the emulsion spend most of its residence time in 
the heat exchanger above the gelation temperature and was thus prone to coalescence.

\section{Effect of coalescence rate}

The coalescence rate is influenced by the presence of surfactant and by the phase ratio. The surfactants reduce the coalescence probability in case of droplet collision, while a larger phase ratio increases the collision rate without affecting the coalescence probability.

An experiment without surfactant was performed and resulted in the formation of a gel block at the bottom of the receiving vessel (Fig. 21a) together with large agglomerates (Fig. 21b), but no spherical particle as it could be observed on Fig. 20 a when surfactants were used.

The formation of a gel block at the bottom of the receiving vessel could only have happened if at least a fraction of the droplets were not gelled at the HE outlet. The fact that this gel block was composed of seemingly agglomerated spherical particles (Fig. 21a) supports the hypothesis of a partial gelation. The HE outlet temperature measured to be $35{ }^{\circ} \mathrm{C}$ is in the range of gelation temperatures evaluated with the rheometer $\left(34 \pm 5^{\circ} \mathrm{C}\right.$, Fig. 10). It is thus our first conclusion that the HE outlet temperature should be to some extent below the measured gelation temperature to ensure no coalescence. Additionally, these observations further demonstrate the effect of the surfactant in hindering the coalescence not only in the HE but also in the receiving vessel when the droplets (or partially gelled particles) sediments together at the bottom as no such gel block was produced in the reference experiment.

Carrying the emulsion gelation with $0.5 \mathrm{wt} . \%$ PGPR but at a higher phase ratio of $33 \mathrm{v} \%$ resulted in large agglomerates of several millimetres in size (Fig. 22a) but also yielded spherical particles (Fig. 22b) as opposed to the trial with no surfactant at lower phase ratio. Comparison of this result to the reference experiment illustrates the effect of a higher collision rate, resulting in a larger coalescence rate and thus producing larger agglomerates. Additionally, comparing this result with the surfactant free trial, we can prove that even with a higher collision rate (at a higher phase ratio), the presence of surfactant could hinder coalescence to a larger extent than simply lowering the collision rate.

\section{Effect of cooling rate}

The next experiment employed the same conditions as the reference one, but without cooling: the emulsion was passed through the HE but no cooling water was flowing. As no stirring was provided in the receiving vessel, most of the droplets coalesced at the bottom and yielded a gel block with oil inclusions (Fig. 23a). Only the small droplets that sedimented slow enough to gel before reaching the bottom of the vessel resulted in gel microparticles (Fig. 23b). Even though slower gelation rates affect the final gel particle size (as demonstrated previously with the batch set-up), providing stirring in the recieving vessel can prevents the complete collapse of the emulsion. It is thus a critical part of the emulsion gelation set-up if the cooling capacity of the heat exchanger is not sufficient to reach the gelation temperature before the suspension is allowed to sediment in the recieving vessel.

As we could not vary the heat exchanger geometry or the cooling water temperature to accelerate the gelation rate, another experiment was performed in which the emulsification was carried out a lower temperature of $80{ }^{\circ} \mathrm{C}$. Indeed, by starting at a lower emulsification temperature, the gelation temperature should be reached faster with the given cooling capacity of the apparatus. This allowed to reduce the temperature of the emulsion at the heat exchanger outlet to $32^{\circ} \mathrm{C}$ and produced spherical particles with no observable agglomerates (Fig. 24).

It is to be noted that the particle produced at $80^{\circ} \mathrm{C}$ (Fig. 24) is larger than the one produced at $90^{\circ} \mathrm{C}$ (Fig. 20) because of the significantly larger viscosity of the starch paste at $80{ }^{\circ} \mathrm{C}$ (see Fig. 13). If one would like to obtain smaller particles and avoid excessive coalescence, the rotation speed of the colloid mill should be increased in order to provide larger shear rate.

As discussed earlier, pea starch melts at $10 \mathrm{wt} . \%$ presented a significantly higher gelation temperature compared to the amylomaize at 7 wt.\% ( 58 vs. $35^{\circ} \mathrm{C}$ ). This effect was exploited to further illustrate the gelation rate effect, and the emulsion of this starch melts was carried out at $90{ }^{\circ} \mathrm{C}$, with $0.5 \mathrm{wt} . \%$ PGPR and with a phase ratio of $50 \mathrm{v} \%$. These conditions did not resulted in the formation of any agglomerate even though the large particles observed on Fig. 25 indicate some degree of coalescence. Such coalescence events are not surprising at such large phase ratio, and these conditions are in no way optimal for proper particle production but are of strong interest for the understanding of the process. Indeed, this experiment demonstrates that a high gelation rate can certainly limit coalescence even in a system where the coalescence rate is expected to be high because of the large phase ratio.

Additionally, the large particles observed in Fig. 25 are a clear sign of coalescence, but the HE outlet temperature $\left(35^{\circ} \mathrm{C}\right)$, well below the system gelation temperature for this system $\left(58^{\circ} \mathrm{C}\right)$, eliminates the possibility to have any coalescence happening in the receiving vessel. The spherical nature of these large particles contrasts with the rough partial coalescence observed in the previous cases (Figs. 20a and $b$ and 22a). This seems to indicate that the coalescence in the heat exchanger would yield large but round particles, while coalescence via sedimentation in the receiving vessel would be at the origin of the rough agglomerate. This observation also applies to the experiments with a lower emulsification temperature (Fig. 24), in which the HE outlet temperature seemed to have been low enough to avoid sedimentation 
induced coalescence and in which the emulsion condition (surfactant and phase ratio) also inhibited coalescence in the HE.

These examples clearly demonstrate that an optimum in gelation and coalescence rates should be reached in order to allow for spherical gel microparticles production without the formation of agglomerates. The use of surfactant is critical for the coalescence control in our set-up as it was not possible to trigger the gelation fast enough before coalescence. Carrying the emulsification at lower temperatures did reduce the agglomerate production by allowing a quicker gelation and using pea starch that gels at higher temperature also proved to reduce the effect of coalescence.

\section{Separation and supercritical drying}

The gel particles were separated from the oil by sedimentation or centrifugation after the addition of a heavier aqueous phase, consisting of $70 \mathrm{wt} . \%$ water and $30 \mathrm{wt} . \%$ ethanol. The addition of ethanol was found to help the particle to transition more efficiently to the aqueous phase (compared to water only), and most of the particles were recovered. Additionally to helping the gel particles transition from the oil to the water phase, the addition of ethanol also allows to start the solvent exchange of the particles. It was then continued with fresh ethanol until the concentration was compatible with the supercritical drying (>95 wt.\%). Finally, the amylomaize starch gel (7 wt.\%) microparticles (present as a slurry in ethanol) were supercritically dried. The resulting aerogel particles are shown in Fig. 26. They had BET surface area of $278 \pm 10 \mathrm{~m}^{2} / \mathrm{g}$. This value falls in the same range as the results obtained for the monolith presented in Fig. 12, demonstrating that the emulsion gelation process did not influenced the final textural properties of the aerogel, allowing, however, its efficient shaping.

\section{Conclusion}

Two emulsion gelation processes for production of starchderived aerogel microparticles were suggested: a batch and semi-continuous process. The formation of starch gels was investigated for two starch types - amylomaize and pea. We showed that amylomaize starch suspensions required higher temperature than pea starch to reach complete dissolution into water. Such a high temperature caused formation of brown particles with the amylomaize starch (possible Maillard reaction).

Using oscillatory rheometry, gelation in starch pastes was investigated. Higher starch concentration resulted in quicker gelation (higher gelation temperature), and above $5 \mathrm{wt} . \%$ pea starch pastes gelled significantly faster than their amylomaize counterparts.
The gelation and retrogradation temperature of the starch pastes were varied, and no significant effect could be observed on the specific surface area of amylomaize starch aerogel. On the other hand, pea starch aerogels produced with gelation and retrogradation carried out at $6^{\circ} \mathrm{C}$ resulted in a specific surface area almost twice as large as the samples processed at $20^{\circ} \mathrm{C}$.

The emulsion gelation was investigated in a batch set-up (stirred vessel), and we showed that the description of the droplet size could neither succeed by considering pure Couette flow (pure shear) nor by using a turbulent viscous model. It appeared that the droplet break-up occurred in the elongational flow produced in the vessel which explained why the pitched blade turbine (axial flow impeller) produced smaller droplets than a flat blade turbine (radial flow impeller).

Additionally, the effect of the surfactant type on the process was demonstrated: Span80 and PGPR were used as surfactants in paraffin oil, and no difference could be observed in term of particle size until an emulsification time of $10 \mathrm{~min}$. Above this time, the Span 80 triggered the gelation and agglomeration of the starch paste droplets resulting in a complete phase separation.

The emulsion gelation of starch pastes was investigated for the first time in a semi-continuous set-up in which the emulsification was performed in a colloid mill. The well-defined Couette flow (pure shear) in such an apparatus allowed the description of the droplet break-up using a critical capillary number from the literature. A counter-current coaxial coiled heat exchanger was used to cool down the emulsion and trigger the gelation of the starch paste droplets demonstrating for the first time a semi-continuous emulsion gelation set-up.

Finally, the starch gel microparticles were supercritically dried, and their specific surface area was not significantly affected by the emulsion gelation method when compared with corresponding monoliths.

Therefore, we suggest to use the emulsion gelation process to produce starch aerogel microparticles in a (semi) continuous way. We hope that the process reported here will enable a broader application of starch aerogels in the life science.

Acknowledgements We are truly thankful to all the students who assisted carrying out the lab work, to Nestlé Product Technology Centre York for the financial support and to Dr. Olaf Häusler from Roquette Frere ${ }^{\circledR}$ for making the starch available to us and for the enlightening discussion.

Funding Information Open Access funding provided by Projekt DEAL.

\section{Compliance with ethical standards}

Conflict of interest The authors declare that they have no conflict of interest.

Open Access This article is licensed under a Creative Commons Attribution 4.0 International License, which permits use, sharing, adaptation, distribution and reproduction in any medium or format, as long as 
you give appropriate credit to the original author(s) and the source, provide a link to the Creative Commons licence, and indicate if changes were made. The images or other third party material in this article are included in the article's Creative Commons licence, unless indicated otherwise in a credit line to the material. If material is not included in the article's Creative Commons licence and your intended use is not permitted by statutory regulation or exceeds the permitted use, you will need to obtain permission directly from the copyright holder. To view a copy of this licence, visit http://creativecommons.org/licenses/by/4.0/.

\section{References}

1. Chidambareswarapattar C, Larimore Z, Sotiriou-Leventis C, Leventis N 2012 Mechanically strong nanoporous polyimides (aerogels) from anhydrides and isocyanates: A structure-property study, in: Abstr. Pap. Am. Chem. Soc., AMER CHEMICAL SOC 1155 16TH ST, NW, WASHINGTON, DC 20036 USA

2. Rigacci A, Marechal JC, Repoux M, Moreno M, Achard P (2004) Preparation of polyurethane-based aerogels and xerogels for thermal superinsulation. J Non-Cryst Solids 350:372-378. https://doi. org/10.1016/j.jnoncrysol.2004.06.049

3. Lee JK, Gould GL, Rhine W (2009) Polyurea based aerogel for a high performance thermal insulation material. J Sol-Gel Sci Technol 49:209-220. https://doi.org/10.1007/s10971-008-1861-6

4. Chidambareswarapattar C, Xu L, Sotiriou-Leventis C, Leventis N (2013) Robust monolithic multiscale nanoporous polyimides and conversion to isomorphic carbons. RSC Adv 3:26459. https://doi. org/10.1039/c3ra43717e

5. Nguyen ST, Feng J, Ng SK, Wong JPW, Tan VBC, Duong HM (2014) Advanced thermal insulation and absorption properties of recycled cellulose aerogels. Colloids Surf Physicochem Eng Asp 445:128-134. https://doi.org/10.1016/j.colsurfa.2014.01.015

6. Fischer F, Rigacci A, Pirard R, Berthon-Fabry S, Achard P (2006) Cellulose-based aerogels. Polymer. 47:7636-7645. https://doi.org/ 10.1016/j.polymer.2006.09.004

7. Demilecamps A, Beauger C, Hildenbrand C, Rigacci A, Budtova T (2015) Cellulose-silica aerogels. Carbohydr Polym 122:293-300. https://doi.org/10.1016/j.carbpol.2015.01.022

8. Rudaz C, Courson R, Bonnet L, Calas-Etienne S, Sallée H, Budtova T (2014) Aeropectin: fully biomass-based mechanically strong and thermal superinsulating aerogel. Biomacromolecules. 15:2188-2195. https://doi.org/10.1021/bm500345u

9. Rudaz C 2013 Cellulose and pectin aerogels: towards their nanostructuration, MINES ParisTech

10. Tkalec G, Knez Ž, Novak Z (2015) Fast production of highmethoxyl pectin aerogels for enhancing the bioavailability of lowsoluble drugs. J Supercrit Fluids 106:16-22. https://doi.org/10. 1016/j.supflu.2015.06.009

11. Quraishi S, Martins M, Barros AA, Gurikov P, Raman SP, Smirnova I, Duarte ARC, Reis RL (2015) Novel non-cytotoxic alginate-lignin hybrid aerogels as scaffolds for tissue engineering. J Supercrit Fluids 105:1-8. https://doi.org/10.1016/j.supflu.2014. 12.026

12. Escudero RR, Robitzer M, Di Renzo F, Quignard F (2009) Alginate aerogels as adsorbents of polar molecules from liquid hydrocarbons: hexanol as probe molecule. Carbohydr Polym 75:52-57. https://doi.org/10.1016/j.carbpol.2008.06.008

13. Mallepally RR, Bernard I, Marin MA, Ward KR, McHugh MA (2013) Superabsorbent alginate aerogels. J Supercrit Fluids 79: 202-208. https://doi.org/10.1016/j.supflu.2012.11.024

14. Mehling T, Smirnova I, Guenther U, Neubert RHH (2009) Polysaccharide-based aerogels as drug carriers. J Non-Cryst
Solids 355:2472-2479. https://doi.org/10.1016/j.jnoncrysol.2009. 08.038

15. Marco ID, Baldino L, Cardea S, Reverchon E (2015) Supercritical gel drying for the production of starch aerogels for delivery systems. Chem Eng Trans:307-312. https://doi.org/10.3303/ CET1543052

16. Ubeyitogullari A, Ciftci ON (2016) Formation of nanoporous aerogels from wheat starch. Carbohydr Polym 147:125-132. https://doi.org/10.1016/j.carbpol.2016.03.086

17. De Marco I, Reverchon E (2017) Starch aerogel loaded with poorly water-soluble vitamins through supercritical CO 2 adsorption. Chem Eng Res Des 119:221-230. https://doi.org/10.1016/j.cherd. 2017.01.024

18. Goimil L, Braga MEM, Dias AMA, Gómez-Amoza JL, Concheiro A, Alvarez-Lorenzo C, de Sousa HC, García-González CA (2017) Supercritical processing of starch aerogels and aerogel-loaded poly( $\varepsilon$-caprolactone) scaffolds for sustained release of ketoprofen for bone regeneration. J CO2 Util 18:237-249. https://doi.org/10. 1016/j.jcou.2017.01.028

19. Garcia-Gonzalez CA, Smirnova I (2013) Use of supercritical fluid technology for the production of tailor-made aerogel particles for delivery systems. J Supercrit Fluids 79:152-158. https://doi.org/10. 1016/j.supflu.2013.03.001

20. Druel L, Bardl R, Vorwerg W, Budtova T (2017) Starch aerogels: a member of the family of thermal superinsulating materials. Biomacromolecules. 18:4232-4239

21. Kenar JA, Eller FJ, Felker FC, Jackson A, Fanta GF (2014) Starch aerogel beads obtained from inclusion complexes prepared from high amylose starch and sodium palmitate. Green Chem:19211930. https://doi.org/10.1039/c3gc41895b

22. Ching SH, Bansal N, Bhandari B (2017) Alginate gel particles-a review of production techniques and physical properties. Crit Rev Food Sci Nutr 57:1133-1152. https://doi.org/10.1080/10408398. 2014.965773

23. Ganesan K, Budtova T, Ratke L, Gurikov P, Baudron V, Preibisch I, Niemeyer P, Smirnova I, Milow B (2018) Review on the production of polysaccharide aerogel particles. Materials. 11:2144. https://doi. org/10.3390/ma11112144

24. Baudron V, Gurikov P, Smirnova I (2019) A continuous approach to the emulsion gelation method for the production of aerogel micro-particle. Colloids Surf Physicochem Eng Asp 566:58-69. https://doi.org/10.1016/j.colsurfa.2018.12.055

25. Kleemann C, Selmer I, Smirnova I, Kulozik U (2018) Tailor made protein based aerogel particles from egg white protein, whey protein isolate and sodium caseinate: influence of the preceding hydrogel characteristics. Food Hydrocoll 83:365-374. https://doi.org/10. 1016/j.foodhyd.2018.05.021

26. García-González CA, Jin M, Gerth J, Alvarez-Lorenzo C, Smirnova I (2015) Polysaccharide-based aerogel microspheres for oral drug delivery. Carbohydr Polym 117:797-806. https://doi.org/ 10.1016/j.carbpol.2014.10.045

27. Alnaief M, Alzaitoun MA, García-González CA, Smirnova I (2011) Preparation of biodegradable nanoporous microspherical aerogel based on alginate. Carbohydr Polym 84:1011-1018. https://doi.org/10.1016/j.carbpol.2010.12.060

28. Wang X, Wang X, Liu L, Bai L, An H, Zheng L, Yi L (2011) Preparation and characterization of carbon aerogel microspheres by an inverse emulsion polymerization. J Non-Cryst Solids 357 : 793-797. https://doi.org/10.1016/j.jnoncrysol.2010.11.015

29. Gu S, Zhai C, Jana SC (2016) Aerogel microparticles from oil-in-oil emulsion systems. Langmuir. 32:5637-5645. https://doi.org/10. 1021/acs.langmuir.6b01043

30. Alnaief M, Smirnova I (2011) In situ production of spherical aerogel microparticles. J Supercrit Fluids 55:1118-1123. https:// doi.org/10.1016/j.supflu.2010.10.006 
31. Vankova N, Tcholakova S, Denkov ND, Ivanov IB, Vulchev VD, Danner T (2007) Emulsification in turbulent flow. J Colloid Interface Sci 312:363-380. https://doi.org/10.1016/j.jcis.2007.03. 059

32. Debet MR, Gidley MJ (2007) Why do gelatinized starch granules not dissolve completely? Roles for amylose, protein, and lipid in granule "ghost" integrity. J Agric Food Chem 55:4752-4760. https://doi.org/10.1021/jf070004o

33. Association of Official Analytical Chemists, Horwitz W, eds., Food composition, additives, natural contaminants, 17th, AOAC International, Arlington, 2000

34. Rao MA (2014) Rheology of fluid, semisolid, and solid foods. Springer US, Boston. https://doi.org/10.1007/978-1-4614-9230-6

35. Leloup VM, Colonna P, Ring SG, Roberts K, Wells B (1992) Microstructure of amylose gels. Carbohydr Polym 18:189-197. https://doi.org/10.1016/0144-8617(92)90063-V

36. Baudron V, Gurikov P, Smirnova I, Whitehouse S (2019) Porous Starch Materials via Supercritical- and Freeze- Drying, 14

37. Lu T, Jane J, Keeling PL (1997) Temperature effect on retrogradation rate and crystalline structure of amylose. Carbohydr Polym 33: $19-26$

38. Ortega-toro R, Jiménez A, Talens P, Chiralt A (2014) Effect of the incorporation of surfactants on the physical properties of corn starch films. Food Hydrocoll 38:66-75. https://doi.org/10.1016/j. foodhyd.2013.11.011

39. Bruijn RRD (1989) Deformation and breakup of drops in simple shear flows. https://doi.org/10.6100/ir318702

40. Hinch EJ, Acrivos A (1979) Steady long slender droplets in twodimensional straining motion. J Fluid Mech 91:401. https://doi.org/ 10.1017/S0022112079000227

41. Alopaeus V, Koskinen J, Keskinen KI, Majander J (2002) Simulation of the population balances for liquid-liquid systems in a nonideal stirred tank. Part 2 - parameter fitting and the use of the multiblock model for dense dispersions. Chem Eng Sci. 57:18151825

42. Kumar S, Kumar R, Gandhi KS (1991) Alternative mechanisms of drop breakage in stirred vessels. Chem Eng Sci 46:2483-2489

43. Bowen R (1986) Unraveling the mysteries of shear-sensitive mixing systems. Chem Eng 93:55-63

44. Yaron I, Gal-Or B (1972) On viscous flow and effective viscosity of concentrated suspensions and emulsions: effect of particle concentration and surfactant impurities. Rheol Acta 11:241-252. https:// doi.org/10.1007/BF01974767

45. Paul EL, Atiemo-Obeng VA, Kresta SM (eds) (2004) Handbook of industrial mixing: science and practice. Wiley-Interscience, Hoboken

46. Wille BM, Langer G, Werner U (2001) The influence of macroscopic elongational flow on dispersion processes in agitated tanks. Chem Eng Technol 24:119-127

47. Kumar S, Ganvir V, Satyanand C, Kumar R, Gandhi KS (1998) Alternative mechanisms of drop breakup in stirred vessels. Chem Eng Sci 53:3269-3280

48. Maindarkar S, Dubbelboer A, Meuldijk J, Hoogland H, Henson M (2014) Prediction of emulsion drop size distributions in colloid mills. Chem Eng Sci 118:114-125. https://doi.org/10.1016/j.ces. 2014.07.032

49. Noui-Mehidi MN, Ohmura N, Kataoka K (2005) Dynamics of the helical flow between rotating conical cylinders. J Fluids Struct 20: 331-344. https://doi.org/10.1016/j.jfluidstructs.2004.12.001

Publisher's note Springer Nature remains neutral with regard to jurisdictional claims in published maps and institutional affiliations. 